\title{
Mineralogy and mixing state of north African mineral dust by online single-particle mass spectrometry
}

\author{
Nicholas A. Marsden ${ }^{1}$, Romy Ullrich ${ }^{2}$, Ottmar Möhler ${ }^{2}$, Stine Eriksen Hammer ${ }^{3}$, Konrad Kandler ${ }^{3}$, Zhiqiang Cui ${ }^{4}$, \\ Paul I. Williams ${ }^{1,5}$, Michael J. Flynn ${ }^{1}$, Dantong Liu ${ }^{1}$, James D. Allan ${ }^{1,5}$, and Hugh Coe ${ }^{1}$ \\ ${ }^{1}$ School of Earth and Environmental Sciences, University of Manchester, Manchester, UK \\ ${ }^{2}$ Institute of Meteorology and Climate Research, Karlsruhe Institute of Technology, Karlsruhe, Germany \\ ${ }^{3}$ Institute of Applied Geosciences, Technische Universitat Darmstadt, Darmstadt, Germany \\ ${ }^{4}$ School of Earth and Environment, University of Leeds, Leeds, UK \\ ${ }^{5}$ National Centre for Atmospheric Science, Manchester, UK
}

Correspondence: Hugh Coe (hugh.coe@ manchester.ac.uk)

Received: 16 July 2018 - Discussion started: 15 August 2018

Revised: 4 February 2019 - Accepted: 5 February 2019 - Published: 21 February 2019

\begin{abstract}
The mineralogy and mixing state of dust particles originating from the African continent influences climate and marine ecosystems in the North Atlantic due to its effect on radiation, cloud properties and biogeochemical cycling. However, these processes are difficult to constrain because of large temporal and spatial variability, and the lack of in situ measurements of dust properties at all stages of the dust cycle. This lack of measurements is in part due to the remoteness of potential source areas (PSAs) and transport pathways but also because of the lack of an efficient method to report the mineralogy and mixing state of single particles with a time resolution comparable to atmospheric processes, which may last a few hours or less. Measurements are equally challenging in laboratory simulations where dust particles need to be isolated and characterised in low numbers whilst conditions are dynamically controlled and monitored in real time. This is particularly important in controlled expansion cloud chambers (CECCs) where ice-nucleating properties of suspended dust samples are studied in cold and mixed phase cloud conditions.

In this work, the mineralogy and mixing state of the fine fraction $(<2.5 \mu \mathrm{m})$ in laboratory-suspended dust from PSAs in north Africa were made using novel techniques with online single-particle mass spectrometry (SPMS) and traditional offline scanning electron microscopy (SEM). A regional difference in mineralogy was detected, with material sourced from Morocco containing a high number fraction of illitelike particles in contrast to Sahelian material which contains
\end{abstract}

potassium- and sodium-depleted clay minerals like kaolinite. Single-particle mixing state had a much greater local variation than mineralogy, particularly with respect to organicbiological content. Applying the same methods to ambient measurement of transported dust in the marine boundary layer at Cabo Verde in the remote North Atlantic enabled the number fractions of illite/smectite clay mineral (ISCM), non-ISCM and calcium-containing particles to be reported at a $1 \mathrm{~h}$ time resolution over a 20-day period. Internal mixing of silicate particles with nitrate, chlorine and organic-biological material was also measured and compared to that in the suspended soils.

The results show SPMS and SEM techniques are complementary and demonstrate that SPMS can provide a meaningful high-resolution measurement of single-particle mineralogy and mixing state in laboratory and ambient conditions. In most cases, the differences in the mineralogical composition between particles within a soil sample were small. Thus, particles were not composed of discrete mineral phases. In ambient measurements, the ISCM and nitrate content was found to change significantly between distinct dust events, indicating a shift in source and transport pathways which may not be captured in offline composition analysis or remote sensing techniques. 


\section{Introduction}

Aeolian dust derived from sources in north Africa has a substantial impact on the climate and ecosystems in the North Atlantic, but our ability to simulate climate response is poor (Evan et al., 2014; Kok et al., 2018). During aeolian transport, mineral dust influences many atmospheric processes, many of which are a function of mineralogy as well as particle size and elemental composition (Formenti et al., 2011). In addition, deposition of terrestrial material into the North Atlantic ocean is important to the biogeochemical cycle of marine ecosystems as it represents a major source of iron, nitrogen and phosphorous (Baker et al., 2003; Jickells et al., 2005).

In recent years, the composition of dust has attracted extra attention because the mineral phase is thought to influence the ice-nucleating (IN) ability of single particles (Zimmermann et al., 2008; Connolly et al., 2009; Möhler et al., 2008; Cziczo et al., 2009; Niedermeier et al., 2011; AugustinBauditz et al., 2016) and therefore influences climate by changing the radiative properties of ice and mixed phase clouds (Rosenfeld et al., 2001; DeMott, 2003), which represent some of the biggest uncertainties in weather and climate change prediction (DeMott et al., 2010; Carslaw et al., 2013). The mechanisms involved are not well understood, and many analytical techniques have been developed to help further our understanding of this important single-particle process (Hoose and Möhler, 2012; Hiranuma et al., 2015). Recently, it has been demonstrated that the mineral phase has an influence on heterogeneous freezing temperature, with some feldspar group minerals proving to be particularly efficient ice-nucleating particles (INPs) in droplet freezing experiments with nominally pure laboratory-prepared mineral samples (Atkinson et al., 2013; Harrison et al., 2016; Peckhaus et al., 2016).

To complicate things further, cloud chamber studies of silicate mineral dust coated with secondary sulfate and organics have demonstrated that this mixing can alter hygroscopicity and change the ice-nucleation efficiency of a particle but is dependent on the ice-forming mechanism (Möhler et al., 2008; Sullivan et al., 2010a, b; Niedermeier et al., 2011; Reitz et al., 2011). In addition, laboratory studies have suggested that the internal mixing state, particularly metal oxide-clay mineral assemblages, has an important influence on direct radiative properties of dust (Nousiainen et al., 2009; Jeong and Nousiainen, 2014; Kemppinen et al., 2015; Di Biagio et al., 2017; Caponi et al., 2017). This highlights the need for measurement of single-particle composition, including both mineralogy and internal mixing state, but is extremely challenging in natural dust particles due to complex mineralogy and mixing state that is a product of the source area, emission mechanism and atmospheric processing.

Major dust emission occurs in sparsely vegetated arid areas but only when the surface properties and meteorological conditions are favourable (Knippertz and Todd, 2012), which can be difficult to predict in dust emission models (Heinold et al., 2013). During the summer months in north Africa, the process of dust advection is associated with moist convection (Schepanski et al., 2009b) and results in a complex structure of stratified layers of warm dry air with very high dust concentrations (Dunion and Marron, 2008). Satellite observations show that these layers can be transported westward in discrete plumes over the Atlantic Ocean towards the Caribbean basin (Kaufman et al., 2005; Zhu et al., 2007; Doherty et al., 2008; Tsamalis et al., 2013).

The source of these dust plumes is arid soils that consist of a complex mixture of organic and inorganic material. The inorganic material largely consists of silicate minerals (quartz, feldspars, clay minerals), carbonate and metal oxides that occur as whole grains or mixed mineral phases. The abundance of the mineral phase has a strong grain size dependence, with quartz occurring in the coarse fraction and clay minerals dominating the fine fraction, but the size distribution is modified during emission (Perlwitz et al., 2015a), so that ratios of mineral phases in the lofted mineral dust aerosol may not be completely representative of that of the source soil. Aircraft observations have demonstrated that the size distribution of dust plumes also evolves during transport, which affects optical properties (Ryder et al., 2013), but the contributions from associated changes in composition are not understood.

Measurements of ambient dust properties are needed to inform simulations of dust emission, transport and deposition processes in present-day climate and paleoclimate models. For example, the provenance of mineral dust has been determined by comparing mass fraction ratios of certain mineral phases to the bulk analysis of soils in potential source areas (PSAs) (Caquineau et al., 2002; Scheuvens et al., 2013). Although improved soil maps are available for north Africa (Claquin et al., 1999; Nickovic et al., 2012; Journet et al., 2014), they still lack the spatial resolution required to represent the heterogeneity of soil within a PSA, and this results in an oversimplification of the mineralogical relationships in a given soil type (Scanza et al., 2015). Improvements to emission simulations require validation measurements of size-resolved dust mineralogy and mixing state at varying distances from the source (Perlwitz et al., 2015b).

Identification of the source of transported dust is problematic due to the inhomogeneity of source sediments and the mixing of material during transport. Nevertheless, analysis of bulk mineralogical composition of source sediments can provide markers, with illite/kaolinite ratios being particularly useful (Caquineau et al., 2002). At the Cabo Verde islands, Glaccum and Prospero (1980) analysed day-long exposures of filters collected during the summer of 1974 and concluded that illite and mica were the dominant mineral types deposited in the tropical North Atlantic. In contrast, Kandler et al. (2011a) reported kaolinite as the dominant mineral type and attributed this to the dominance of sources in the Sahel during the summer. 
(a)

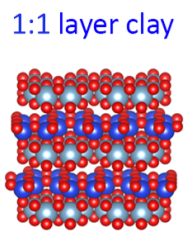

(b)

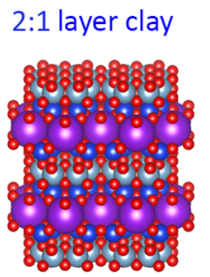

Kaolinite

$\mathrm{Al}_{2} \mathrm{Si}_{2} \mathrm{O}_{5}(\mathrm{OH})_{4}$ (c)

Framework silicate

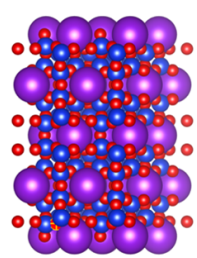

K-feldspar

$\mathrm{K}\left[\mathrm{AISi}_{3} \mathrm{O}_{8}\right]$

Figure 1. The crystal structures of common aluminosilicate minerals (a) $1: 1$ clay mineral structure of kaolinite, (b) the $2: 1$ clay mineral structure of illite and (c) the framework structure of K-feldspar. Colour code is as follows; red: anions $(\mathrm{O}, \mathrm{OH})$, grey: octahedral coordination ( $\mathrm{Al}, \mathrm{Mg}$ ), blue: tetrahedral coordination ( $\mathrm{Si}, \mathrm{Al})$, purple: interstitial complex $(\mathrm{K}, \mathrm{Na}, \mathrm{Ca})$.

Silicates are the most important group of rock-forming minerals and comprise a huge spectrum of compositions and crystal structures. However, the fine fraction of continental soil largely consists of clay minerals with minor amounts of feldspar and quartz (Perlwitz et al., 2015b). Clay minerals are phyllosilicates which consist of 2-D layers of silicon tetrahedrally coordinated with oxygen and aluminum octahedrally coordinated with oxygen and/or hydroxyl. A simple example is that of the mineral kaolinite $\left(\mathrm{Al}_{2} \mathrm{Si}_{2} \mathrm{O}_{5}\left(\mathrm{OH}_{4}\right)\right)$, in which these two layer types are repeated to form a 3-D structure referred to as a 1:1 layer structure (Fig. 1a).

A more complicated structure results in the presence of large cations of potassium, sodium and calcium. The charge and ionic radius of these cations are accommodated in a separate sheet of interstitial cations that must be charge balanced by the tetrahedral and octahedral layers. In the case of potassium, charge balance is achieved with the common $2: 1$ layer structure of illite $\left(\mathrm{K}_{1.5-1.0} \mathrm{Al}_{4}\left[\mathrm{Si}_{6.5-7.0} \mathrm{Al}_{1.5-1.0} \mathrm{O}_{20}\right]\left(\mathrm{OH}_{4}\right)\right)$ in which there are two tetrahedral layers for each octahedral layer (Fig. 1b). These types of clay minerals are expected to be abundant in Saharan dust. For example, in a previous study using transmission electron microscopy (TEM) of sliced dust particles collected on the island of Tenerife in the North Atlantic, the majority of particles of transported Saharan dust were clay-rich agglomerates primarily composed of a matrix of illite/smectite clay minerals (ISCMs) with inclusion of kaolinite and hematite (Jeong et al., 2016).

The feldspar group of minerals is chemically similar to the clay minerals but has a higher atomic content of alkali and alkaline Earth metals which demands a different crystal structure to achieve charge balance. In K-feldspars $\left(\mathrm{K}\left[\mathrm{AlSi}_{3} \mathrm{O}_{8}\right]\right)$, such as microcline and orthoclase, interstitial cations of potassium are fixed in a cavity where they are charge balanced by a 3-D network of tetrahedrally coordinated silicon and aluminum (Fig. 1c). Whilst these minerals

are expected to be less common than clay minerals in fine mineral dust, they may be particularly important in ice nucleation in the atmosphere.

The analytical challenge arises from the fact that common mineral phases are very similar in composition and undergo significant alteration and weathering in the soil, making pure minerals difficult to identify (Formenti et al., 2014). For example, in clay minerals, potassium, sodium and calcium are interchangeable during the weathering process so that composition is not necessarily uniform throughout the crystal lattice. Indeed, the illite structure in Fig. $1 \mathrm{~b}$ is the idealised version of the pure mineral, which is often referred to as an endmember of the illite series. Complete uniformity of clay mineral composition is unlikely on the scale of a single particle or between particles from the same soil sample.

In order to identify the mineral phases present, one must either make an accurate quantitative measurement of the elemental composition or make an analysis of crystal structure. An established approach to both ambient and laboratory measurements is to collect particles on filters and impactors for subsequent offline analysis. Bulk mineralogy can be obtained with crystal structure analysis by X-ray diffraction (XRD), and the composition of individual particles is assessed by advanced microscopy. Scanning electron microscopy (SEM), often combined with energy-dispersive X-ray spectrometry (EDX), is a powerful method for elucidating composition because of the ability to probe the composition of individual dust particles. The application of these techniques can differentiate silicate from calcium-rich particles and shows evidence of heterogeneous reactions in the atmosphere (Ro et al., 2005; Jeong and Chun, 2006; Sobanska et al., 2012).

However, further differentiation of the silicate mineral phase in single particles is hampered by the difficulty in leveraging the full quantitative capability of SEM due to particle morphology effects. Consequently, silicate particles are often reported in compositional groups, which describe the dominant elemental features but not the actual mineral phase (Kandler et al., 2009; Eriksen Hammer et al., 2018). In addition, there are a number of drawbacks to this offline approach including labour-intensive post-sampling analysis and loss of temporal resolution in dynamic situations.

Another, but less common, approach is to use singleparticle mass spectrometry (SPMS) to provide an online assessment of aerosol composition. An advantage of this technique is that the high temporal resolution allows the evolution of the particle composition to be measured in a dynamic setting (Cziczo et al., 2006; Zelenyuk et al., 2009; Gaston et al., 2013), and the instruments can be deployed in line with other techniques such as counterflow virtual impactor (CVI) to measure ice residuals (Cziczo et al., 2003; Gallavardin et al., 2008; Baustian et al., 2012; Zelenyuk et al., 2015; Worringen et al., 2015; Schmidt et al., 2017). However, compositional analysis with SPMS is fraught with difficulties relating to poor reproducibility and the non-quantitative nature of the measurement associated with instrument function and parti- 
cle matrix effects (Reilly et al., 2000; Sullivan and Prather, 2005; Murphy, 2007; Hatch et al., 2014).

The matrix effects arise from the incomplete desorption of the particle and the subsequent competitive ionisation of atoms and molecular fragments, so that covariance of analyte signals is relative to ionisation energy and electron affinity of the surrounding matrix (Reinard and Johnston, 2008). In circumstances where the composition of the matrix is known a priori, careful calibration with a suitable proxy can produce quantitative or semi-quantitative measurements of an analyte within a single particle (Gross et al., 2000; Bhave et al., 2002). However, if the particle matrix is complex, such as in soils and transported dust, this type of calibration cannot be made due to the lack of a suitable proxy.

Despite these limitations, SPMS can characterise a particle population by classifying particle types and measuring temporal trends in particle number concentrations using cluster analysis (Hinz et al., 2006; Rebotier and Prather, 2007; Gross et al., 2010). Although the reported number concentrations are not fully quantitative (Murphy, 2007), a relative trend in certain particle types can be realised. This technique has been used to discriminate mineral dust particles from other refractory aerosol types, such as sea salt (Sullivan et al., 2007a; Dall'Osto et al., 2010; Fitzgerald et al., 2015; Schmidt et al., 2017), but cannot differentiate the actual mineral phase of silicates within dust particles. More recently, a machine learning technique has shown promise for the classification of mineral dusts of similar composition (Christopoulos et al., 2018), but this technique also requires suitable mineral dust proxies for training data.

In a previous study using a single-particle laser ablation aerosol particle time-of-flight mass spectrometer (LAAPTOF, AeroMegt GmbH), Marsden et al. (2018) presented a novel method for the assessment of single-crystal structure that, when used in tandem with the more typical elemental composition measurement, performed an online differentiation of single particles of kaolinite, illite and Kfeldspar mineral phases. In the present study, we applied a refined version of these techniques to suspended natural soils sampled at the Aerosol Interactions and Dynamics in the Atmosphere (AIDA) facility at the Karlsruhe Institute of Technology (KIT), as part of the Ice-Nuclei Research Unit (INUIT) programme studying heterogeneous ice formation in the atmosphere (https://www.ice-nuclei.de/ the-inuit-project/, last access: 15 February 2019). The results of analysing soil from PSAs in north Africa were used to interpret ground-based ambient measurements of transported dust at Praia, Cabo Verde, in the tropical North Atlantic during the summer of 2015 as part of the Ice in Clouds Experiment - Dust (ICE-D) campaign.

\section{Methods}

A limited number of mineral phases were chosen to create fingerprints to which the more varied mineralogy of naturally occurring sediments could be compared. Nominally pure samples of illite, Na-montmorillonite and kaolinite, along with orthoclase (K-feldspar) and plagioclase (Na-feldspar), were used to represent the endmembers of the clay minerals and feldspar groups, respectively. This is based on the assumption that the fine fraction $(<2.5 \mu \mathrm{m})$ continental sediment is primarily composed of aluminosilicate clays and feldspars. Quartz and carbonate minerals are not considered with subcompositional analysis due to the inability of the LAAPTOF to efficiently ablate pure quartz and the apparent lack of a clear carbonate signal, respectively. In ambient dust, calcium-rich particles are considered separately to aluminosilicate particles after being separated using traditional cluster analysis techniques.

The LAAPTOF instrument and data analysis methods are described below, along with SEM-EDX methods used to obtain elemental composition of the laboratory-suspended dust for method validation. The experimental setups of the INUIT09 laboratory campaign and ICE-D ambient measurement are also described in this method section.

\subsection{LAAPTOF single-particle mass spectrometry}

In a previous study, Shen et al. (2018) showed that the LAAPTOF single-particle mass spectrometer is capable of distinguishing the composition of particles in the ambient environment using a combination of fuzzy clustering and reference-based spectra classification, whilst Ahern et al. (2016) demonstrated a positive correlation between ion signals of organic markers and the quantity of condensed organic coating, despite inhomogeneity in the soot core of the particles. These studies show that the LAAPTOF is an appropriate platform for studying the composition and internal mixing state of refractory aerosol.

In SPMS, aerosol is directly introduced into the instrument via a pumped inlet so that sample collection and preparation are not required. Particle composition is analysed by timeof-flight mass spectrometry (TOFMS) after laser desorption ionisation (LDI) of individual particles using a high-powered UV laser. The LAAPTOF instrument features an aerodynamic lens inlet, optical particle detection, LDI ion source and bipolar TOFMS as previously described by Gemayel et al. (2016). Within the instrument, LDI is performed by ArF excimer laser (model EX5, GAM Laser Inc.), set to deliver 3-5 $\mathrm{mJ}$ per pulse of $193 \mathrm{~nm}$ radiation with a pulse width of $8 \mathrm{~ns}$.

Like all single-particle mass spectrometers, the LAAPTOF measurements are subject to a number of biases that result in preferential transmission, detection and ablation efficiencies of certain particles (Murphy, 2007). The instrument used in this investigation features a modified 
particle detection system based on a fibre-coupled laser delivery that allows the simple interchange of laser systems of different wavelengths. The instrument is capable of providing size-resolved composition measurements for up to 200 particles per second in the size range of approximately $0.4-2.5 \mu \mathrm{m}$, but the actual detection efficiency of particles within this range depends on the size, shape and composition, as well as the wavelength of the optical detection system. Differences in instrument setup between the laboratory and ambient measurements that may impact the comparison of the two data sets are presented in Sect. S1 in the Supplement.

Laboratory evaluation of the fiber-coupled laser system indicated that the peak detection efficiency is 0.25 with spherical particles (Marsden et al., 2016), but the overall efficiency of the instrument also depends on ablation efficiency with respect to particle composition. In a study of nominally pure mineral samples, Marsden et al. (2018) reported the number of optically detected particles that produced mass spectra (i.e. ablation efficiency or hit rate) was 0.29 and 0.14 for illite and kaolinite, respectively, but was also dependent on the amount of impurities such as titanium. Furthermore, from the authors' own experience, pure quartz has an ablation efficiency close to zero and is not considered in our analysis but is unlikely to be a major component in the fine fraction in any case. The potential maximum overall efficiency (detection efficiency multiplied by ablation efficiency) of the LAAPTOF measurement of clay mineral ranges from 0.0725 for pure spherical particles of illite to 0.035 for pure spherical particles of kaolinite. The exact efficiency of the instrument is not known in most situations because the size, shape and composition of the particles would have to be known a priori for accurate calibration.

\subsubsection{Crystal structure analysis of silicates}

In a study of ion formation mechanism, Marsden et al. (2018) showed that the ionisation potential and coordination of interstitial cations has a strong influence on how the crystal structure breaks apart during LDI process of silicate particles. This is exploited for the differentiation of the mineral phase by the measurement of average ion arrival of the $\mathrm{O}^{-}$ and $\mathrm{SiO}_{3}^{-}$ion species, which is thought to record the initial kinetic energy of the ionic fragments during ablation.

With this technique, we can compare the structure of soil dust samples to nominally pure mineral samples on a particle-by-particle basis. Laboratory calibrations have demonstrated that for ISCM the abundance of exchangeable sodium and potassium cations results in a unique range of $\tau$ values between 0.2 and 0.58 . Feldspars typically produce $\tau$ values $>0.58$ (Fig. 2) due to the interlocking nature of the interstitial cation in their crystal structure. Kaolinite and amorphous glass produces $\tau$ values close to 1 due to the complete absence of interstitial cations and lack of crystal structure, respectively.
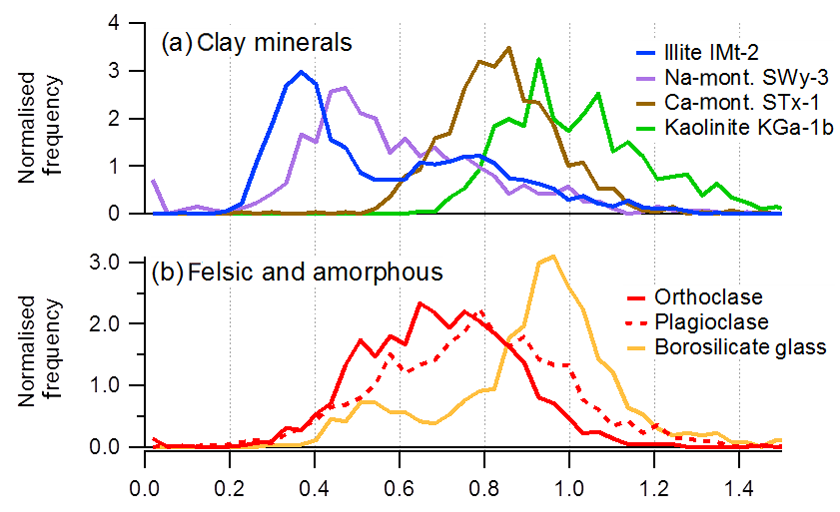

$(\tau)$

Figure 2. The differentiation of reference minerals using crystal structure analysis described by Marsden et al. (2018). The peak shift ratios $(\tau)$ were calculated from ion arrival times from individual particles in the mass spectrometer, rather than conventional peak area analysis for elemental composition. Nominally pure mineral dust was sampled after dispersion in a dust tower: (a) nominally pure clay minerals from the clay mineral society and (b) orthoclase (K-feldspar), plagioclase (Na-feldspar) and borosilicate glass.

\subsubsection{Subcompositional analysis of silicates}

Subcompositional analysis is a technique that is commonly used for the analysis of complex chemical relationships in circumstances in which the full composition of a substance is impossible to obtain, such as in whole-rock geochemical analysis (Pawlowsky-Glahn and Egozcue, 2006), where it is convenient to describe the composition in terms of a relative measurement of carefully chosen components. The ternary diagram provides an intuitive way of displaying relative information whilst avoiding some of the subcompositional incoherence associated with two component systems. The technique has been applied to the single-particle analysis of natural Asian mineral dust using SEM (Yuan et al., 2004) and transported Asian dust using SPMS (Sullivan et al., 2007a). It is particularly well suited to SPMS because the composition obtained from the mass spectra is inherently subcompositional due to the matrix effect.

Subcompositional analysis was used to produce fingerprints of pure mineral phases using the ternary system $\mathrm{Al}^{+}+$ $\mathrm{Si}^{+}, \mathrm{K}^{+}$and $\mathrm{Na}^{+}$cations readily observed in the SPMS of mineral dust $(m / z 27,28,39$ and 23, respectively). Source clay material from the clay mineral society and crushed feldspar crystals were suspended in a homemade dust tower in the experiment described in Marsden et al. (2018). Elemental composition and mineralogy of these samples have been previously characterised and can therefore be used as reference fingerprints for comparison with natural soil. Ternary diagrams of the clay minerals and feldspar standards are displayed separately in Fig. 3.

The 2-D space in these diagrams is non-linear and, due to the matrix effect, a fully quantitative composition cannot be 

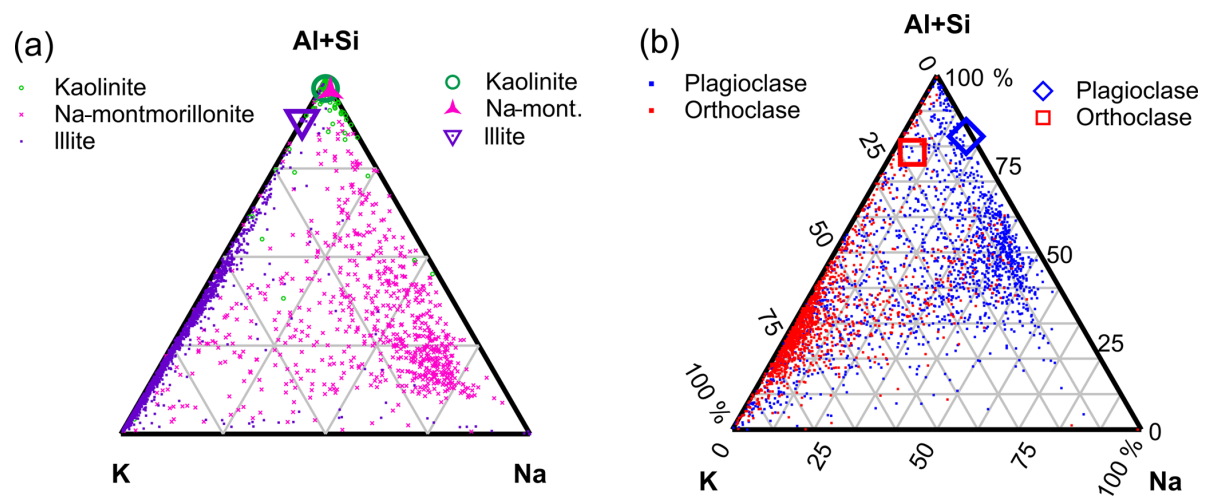

Figure 3. The differentiation of reference minerals using subcompositional analysis. Each dot in the ternary plots represents the composition of a single particle calculated from $\mathrm{Al}+\mathrm{Si}, \mathrm{K}$ and $\mathrm{Na}$ peak areas in the mass spectra. Larger icons represent bulk composition by $\mathrm{X}$-ray fluorescence $(\mathrm{XRF})$ analysis. Nominally pure mineral dust was sampled after dispersion in a dust tower: (a) nominally pure clay minerals illite (1806 particles), kaolinite (1388 particles) and Na-montmorillonite (800 particles) from the clay mineral society and (b) orthoclase (K-feldspar, 1318 particles) and plagioclase (Na-feldspar, 1568 particles).

deduced from these plots alone, but it is interesting to note that K-feldspar appears less K- and Na-rich than illite clay despite the structural formula and X-ray fluorescence (XRF) analysis of the bulk sample indicating the contrary. This is because the tetrahedral framework of the feldspar makes the release of interstitial $\mathrm{K}^{+}$and $\mathrm{Na}^{+}$without also releasing $\mathrm{Al}^{+}$ improbable, whereas they can be released independently of $\mathrm{Al}^{+}$from the weakly bonded interlayer in $2: 1$ clay structure.

Although the elemental subcomposition measurement is clearly non-quantitative with respect to bulk XRF analysis, the measurement is semi-quantitative (relative) with respect to samples of minerals with the same crystal structure. For example, a clear separation between $\mathrm{K}$ - and $\mathrm{Na}$-rich feldspar is apparent in Fig. 3, which is relative to their actual elemental ratios. This is not true if comparing the clay mineral illite with the framework silicate K-feldspar, which would not be easily distinguishable from each other if plotted in the same space, despite the clear differences in elemental composition. It is therefore necessary to apply crystal structure analysis to achieve semi-quantitative composition and distinguish clay minerals from feldspar when analysing natural soils with SPMS.

\subsubsection{Subcomposition analysis of internal mixing state}

Internal mixing of non-mineral species can occur during soil formation or during transport in the atmosphere where heterogeneous reactions take place on the surface of the particle (Usher et al., 2003). Reactions with nitric, sulfuric and organic acids can produce nitrate, sulfate and organics on the particle surface, respectively. Reference spectra obtained with the LAAPTOF during the FIN-1 campaign show the presence of sulfate marker $\mathrm{HSO}_{4}(\mathrm{~m} / z$ 97) on particles after mixing suspended feldspar with ozone and sulfuric acid in the AIDA chamber (Fig. 4b). Similarly, organic markers $\mathrm{C}_{2}, \mathrm{C}_{2} \mathrm{H}$ and $\mathrm{C}_{2} \mathrm{H}_{2}(m / z 24,25,26)$ appear on particles after mixing suspended feldspar with ozone and $\alpha$-pinene (Fig. 4c). Only small organic fragments are observed due to the extensive fragmentation of organic molecules. These ion combinations have also been observed on ambient mineral dust using SPMS instruments (Silva and Prather, 2000; Sullivan et al., 2007a; Fitzgerald et al., 2015) but may also be derived from black carbon mixed with the particle as well as charred organics.

In ambient dust, organic or biological material may have been mixed with a dust particle in the soil before emission. Indeed, the transport of microorganisms in dust storms is a human health concern (Griffin, 2007). Recently, Yamaguchi et al. (2012) provided direct evidence of bacterial cells on Asian dust particles and demonstrated a global dispersion pathway through dust transport. The internal mixing of biological material with dust particles is therefore of interest. LAAPTOF reference spectra of bacteria, also from the FIN1 campaign, show strong signals of $\mathrm{CN}$ and $\mathrm{CNO}(\mathrm{m} / \mathrm{z} 26$, 42) (Fig. 4d) representing fragments of nitrogen-containing organic compounds. These markers have been attributed to compounds of biological origin (Pratt et al., 2009; Cahill et al., 2012; Creamean et al., 2013), although other studies have found these markers in aerosol where biological components were not expected (Sodeman et al., 2005; Zawadowicz et al., 2017; Wonaschuetz et al., 2017). Consequently, we describe these markers as organic-biological (org-bio hereafter).

Internal mixing of natural soil samples with non-minerals in this work are considered with the ternary subcomposition $\mathrm{Cl}^{-}, \mathrm{CN}^{-}+\mathrm{CNO}^{-}, \mathrm{SO}_{4}^{-}$. These markers represent compounds that could be present in soils and ambient dust but are not present in silicate mineral structure. Phosphate marker $\mathrm{PO}_{3}^{-}$is not considered because it could be derived from the calcium phosphate mineral apatite as well as biological material; therefore, it is not a reliable indicator of biological mix- 

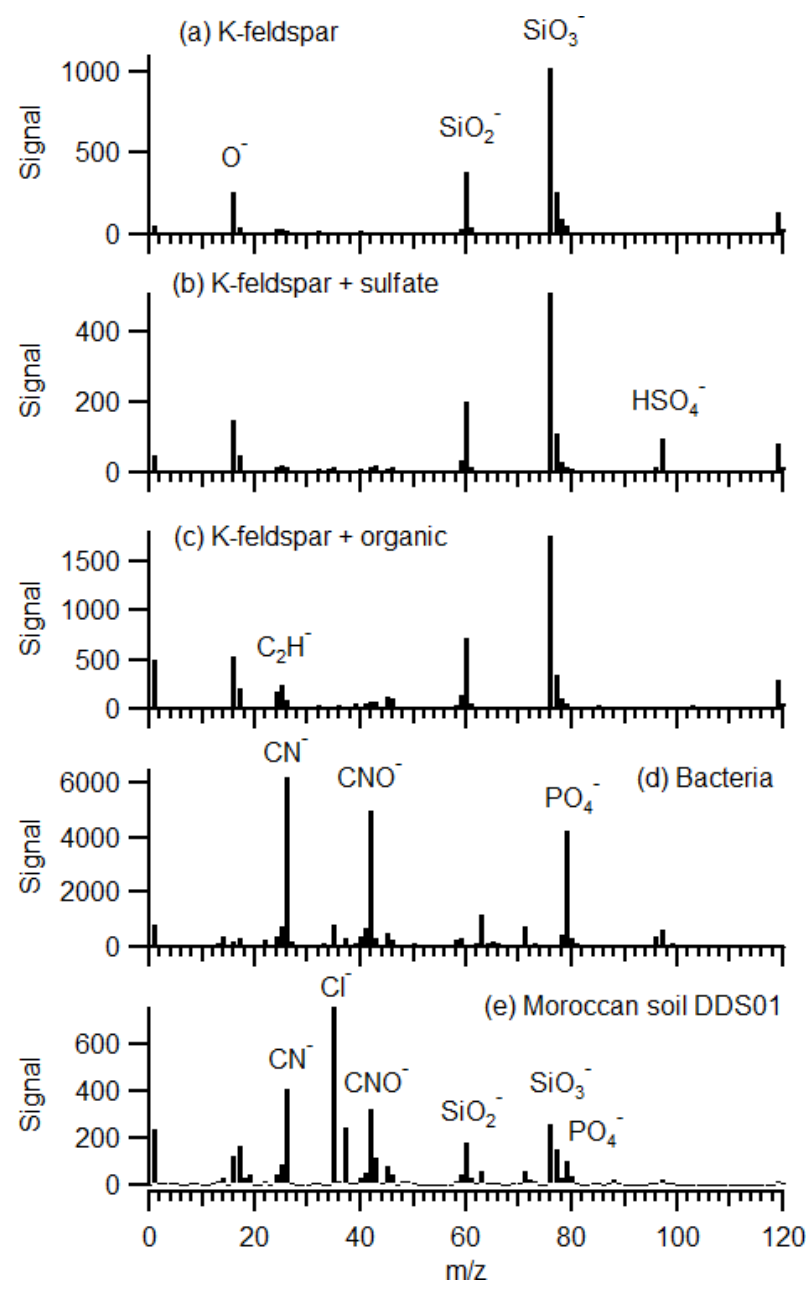

Figure 4. Average negative ion mass spectra (200 particles) of resuspended material in the AIDA chamber during the FIN-1 campaign: (a) pure K-feldspar, (b) K-feldspar with sulfate coating, (c) K-feldspar with organic coating, (d) bacteria and (e) Moroccan soil dust DDS01 during INUIT09.

ing state. The $\mathrm{Cl}^{-}$elemental ion is included despite it also having mixed provenance such as primary chlorides or secondary uptake of $\mathrm{HCl}$ (Sullivan et al., 2007b), because it is preferentially ionised due to very high electron affinity and therefore is included as a reference that would otherwise perturb the measurement. It is also an indication of the purity of silicate particles, as pure fresh silicate should not contain chlorine.

\subsection{Scanning electron microscopy}

Particles were sampled from the AIDA chamber with a single-stage nozzle impactor $(50 \%$ low cut-off diameter at approximately $0.1 \mu \mathrm{m}$ aerodynamic diameter; for specifications, see Kandler et al., 2007) on nickel grids (TEM grids type S162N9, Plano, Wetzlar, Germany). The inlet was con- nected to a sampling line on the AIDA chamber and the sample time varied between 12 and $16 \mathrm{~min}$.

All samples were analysed with computer-controlled scanning electron microscopy (ccSEM) using a FEI Quanta 400 FEG instrument (FEI, Eindhoven, the Netherlands) equipped with an energy-dispersive X-ray detector, X-Max150 (Oxford, Oxfordshire, United Kingdom) and the Oxford software Aztec (version 3.3 SP1). An acceleration voltage of $12.5 \mathrm{keV}$, spot size 5 , a working distance of $10 \mathrm{~mm}$ and high vacuum conditions $\left(10^{-5} \mathrm{hPa}\right)$ were used for all samples. Backscatter electron images were used to segment particles from substrate. The particles of interest were measured with a $4 \mathrm{~s}$ counting time for X-ray microanalysis. The TEM grids were mounted in a copper sample holder (avoiding interference with chemical composition of the particle) equipped with a beam trap (maximising the characteristicpeak-to-background ratio).

Chemical composition of all elements with atomic number higher than $3(\mathrm{Li})$ was determined with energy-dispersive $\mathrm{X}$-ray microanalysis. A sorting step after ccSEM was performed to remove particles with low X-ray counts (due to shading effects) and features of the TEM grid. Between 159 and 776 aluminosilicates were detected per sample, with the highest abundance of particles at an average diameter of $200 \mathrm{~nm}$.

The traditional method for reporting the composition of aerosol particles involves the classification of particles into compositional groups using a variety of elemental ratios and boundary rules, e.g. Kandler et al. (2007, 2011b); Young et al. (2016). However, these classification systems are impossible to apply to SPMS due the matrix effects that skew and suppress elemental ratios. We therefore choose to display the SEM composition as ratios of $\mathrm{Al} / \mathrm{Si},(\mathrm{K}+\mathrm{Na}) / \mathrm{Si}$ and $(\mathrm{Fe}+\mathrm{Mg}) / \mathrm{Si}$, which leverages the quantitative ability to produce a representation of the interstitial cation and aluminosilicate structure that can be intuitively compared to the ternary diagrams obtained by SPMS.

A scatterplot of single-particle average chemical composition is plotted in Fig. 5a. This demonstrates that pure minerals can potentially be differentiated using quantitative $\mathrm{Al} / \mathrm{Si}$ ratio and the $(\mathrm{K}+\mathrm{Na}) / \mathrm{Si}$ (cation to silicate) ratio. For example, the pure kaolinite clay mineral has the highest $\mathrm{Al} / \mathrm{Si}$ ratios $(\approx 1)$ but no $(\mathrm{K}+\mathrm{Na})$ content. In general, the decreasing $\mathrm{Al} / \mathrm{Si}$ ratio must be balanced by increasing cation/Si ratio in clay minerals.

\subsection{INUIT09 laboratory-suspended dust experiment}

\subsubsection{Experiment setup}

For the aerosol generation during the INUIT09 campaign, the natural dust samples were sieved to diameters less than $75 \mu \mathrm{m}$ and injected in either the AIDA cloud chamber or the aerosol preparation and characterisation (APC) chamber. For injection, a rotating brush generator linked to a cyclone im- 
(a) Pure minerals
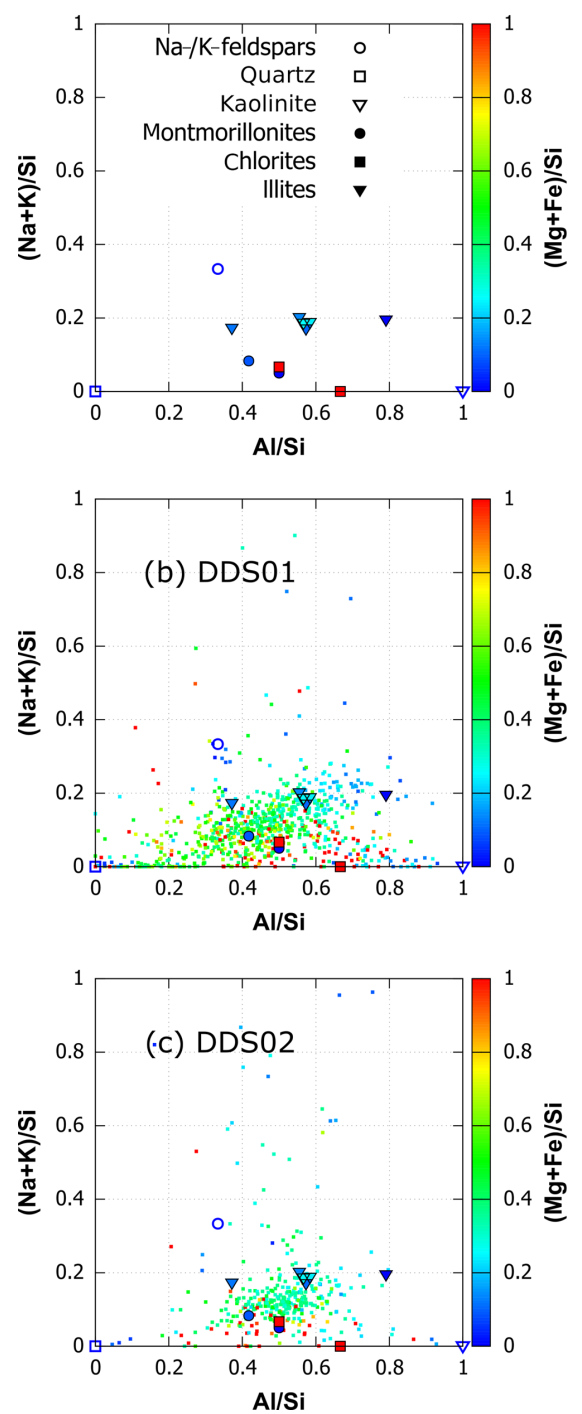
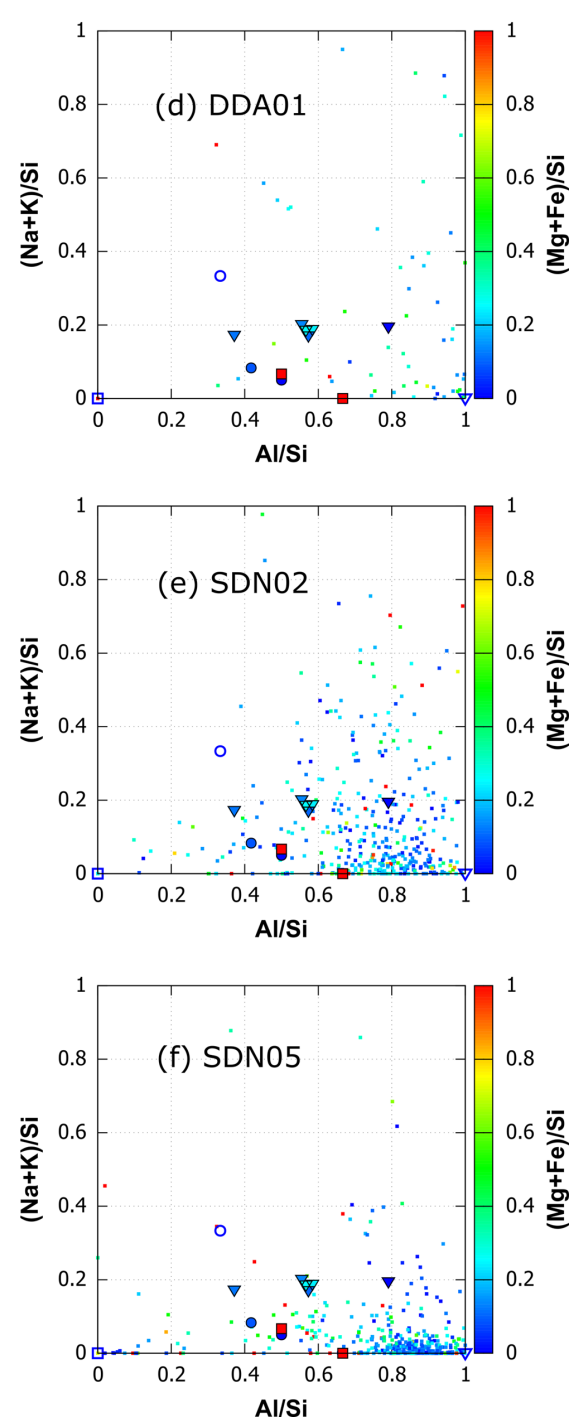

Figure 5. Elemental subcomposition diagrams of suspended natural soil samples (INUIT09) by SEM EDX analysis: (a) average composition of nominally pure mineral samples, (b) DDS01, (c) DDS02, (d) DDA01, (e) SDN02 and (f) SDN05. Ratios are calculated from atomic percentage.

pactor was used, resulting in aerosol particles with aerodynamic diameters of less than about $5 \mu \mathrm{m}$. The dust number concentration in the AIDA chamber was initially between 200 and $300 \mathrm{~cm}^{-3}$ and in the APC chamber between 1000 and $5000 \mathrm{~cm}^{-3}$. The number concentrations and size distribution of the dispersed aerosol are detailed in Sect. S2 in the Supplement.

During this study, the single-particle mass spectrometer LAAPTOF was either connected to the AIDA chamber or the APC, and sampled for about $1 \mathrm{~h}$ during each experiment. During the sampling time, both the AIDA chamber and APC chamber were held to nearly constant temperature (either -16 or $-21^{\circ} \mathrm{C}$ in AIDA and $25-27^{\circ} \mathrm{C}$ in APC) and pressure
(998-1010 hPa in AIDA and 990-1005 hPa in APC) conditions.

\subsubsection{Soil sampling locations}

Soil samples from two specific ecoclimatic zones were suspended at the AIDA facility: the mountainous north-west margin of the Sahara and the west-central Sahel beyond the southern margin of the Sahara (hereafter named Sahel dust). These PSAs were chosen because there are likely to be differences in mineralogical composition between the two zones. Analyses of surface material across north Africa are scarce, but the available studies demonstrate a north-south decease in illite/kaolinite $(\mathrm{I} / \mathrm{K})$ ratio in the clay fraction (Caquineau et al., 2002; Scheuvens et al., 2013; Formenti et al., 2014) 
mainly due to differences in diagenetic history between dry and wet climate zones.

The sampling locations (Table 1) of the natural arid soils are displayed in Fig. 6. Moroccan dust samples were collected in the Mhamid region, on the upper Draa Valley, Morocco, during the Saharan mineral dust experiment (SAMUM) (Ansmann et al., 2011). The Draa Valley is a large geographical feature on the southern edge of the Anti-Atlas Mountains, beyond which is the Sahara desert of Algeria. All sampling locations fall within unit 1336 in the Digital Soil Map of the World (DSMW), compiled by the Food and Agriculture Organization (FAO) of the United Nations.

The samples of Sahel soil were collected from diverse geographical locations in Niger and Burkina Faso. All three sampling locations fall within the zone of kaolinite-rich soil (Fig. 6), where the DSMW indicates cation exchange capacity (CEC) $<35 \mathrm{cmol} \mathrm{kg}^{-1}$.

\subsection{Ambient measurement at Cabo Verde during ICE-D}

The Cabo Verde archipelago is a favourable location for remote marine measurements. Situated some $800 \mathrm{~km}$ off the west coast of north Africa (Fig. 6), it is a site at which long-term measurements of greenhouse gases, trace gases and aerosol properties are recorded (Carpenter et al., 2010). Notable studies of mineral dust composition in the area include long-term filter sample collection at Cabo Verde atmospheric observatory (CVAO) (Patey et al., 2015) and Praia, Santiago Island (Salvador et al., 2016), and filter collection at Praia airport, Santiago Island, for the SAMUM campaign in January-February 2008 (Kandler et al., 2011a).

Ground-based ambient measurements during ICE-D took place in the mobile Manchester Aerosol Laboratory located within the perimeter of Praia International Airport, Santiago Island, Cabo Verde $\left(14^{\circ} 57^{\prime} \mathrm{N}, 23^{\circ} 29^{\prime} \mathrm{W} ; 100 \mathrm{~m}\right.$ a.s.l. $)$, approximately $1500 \mathrm{~m}$ from the coast and $150 \mathrm{~m}$ from the airport runway. The main airport terminal and the outskirts of the city of Praia were 400 and $2500 \mathrm{~m}$ downwind of the prevailing NE wind, respectively. Aerosol was sampled via a $15.24 \mathrm{~cm}$ plastic inlet fixed to a $10 \mathrm{~m}$ tower and pumped at $185 \mathrm{~L} \mathrm{~min}^{-1}$. The flow was distributed to a suite of online instruments, including the LAAPTOF, via a system of $48 \mathrm{~mm}$ ID lines isokinetically sampled from the main inlet, and heated to $19^{\circ} \mathrm{C}$.

\section{Results and discussion}

\subsection{Single-particle analysis of laboratory-suspended natural soil (INUIT09)}

The sampling of particles took place after dispersing the source material in the APC chamber using a rotating brush generator. The resulting particle concentration and size distribution were dynamic but was typically on the order of
$1000 \mathrm{~cm}^{-3}$ with a particle size mode at $200 \mathrm{~nm}$ (see Sect. S2 in the Supplement), which is below the lower size cut of the LAAPTOF, but not the filter collection. Therefore, the two measurement techniques are not performed on the exact same particle sizes. Still, both measurements represent the fine fraction $(<2.5 \mu \mathrm{m})$ of the dispersed dust.

\subsubsection{Silicate mineralogy of laboratory-suspended soil (INUIT09)}

SEM EDX analysis of the suspended soil shows that the composition of single particles within each soil type varies in a continuous distribution rather than in distinct clusters (Fig. 5). A distinct difference in the elemental composition of soil from the northern Sahara and the Sahel exists in these diagrams, particularly with respect to the $\mathrm{Al} / \mathrm{Si}$ ratio. The Moroccan soils (Fig. 5b-c) have a spread in compositions close to the illite plotted on the diagram, with the DDS01 samples being more diverse than the DDS02. In contrast, the soil from the Sahel (Fig. 5c-f) consists of material with a higher $\mathrm{Al} / \mathrm{Si}$ ratio which approaches the composition of the plotted kaolinite. This is in agreement with CEC measurements of sediments which show that kaolinite fraction in soils increases in the Sahel region compared to the northern region of the Sahara (Scheuvens et al., 2013).

SPMS mineralogical analysis proceeded by considering the relative abundance between $\mathrm{K}, \mathrm{Na}$ and $\mathrm{Al}+\mathrm{Si}$, which together define the phase of many minerals in the continental crust. This subcompositional analysis was previously applied to nominally pure mineral samples from the Clay Minerals Society (CMS) to provide a fingerprint reference for the common clay mineral phases (Fig. 7a). The same analysis applied to Moroccan dust (Fig. 7a-c) and Sahelian dust (Fig. 7e-g) shows key differences between the composition of the two ecoclimatic zones, with Moroccan dust tending towards an illite composition and Sahelian dust tending to a kaolinite composition, in agreement with the SEM EDX analysis.

Application of the crystal structure analysis (colour function in Fig. 7) to each particle indicates that the majority of the particles are of a $2: 1$ clay structure, even in Sahelian dust particles that have a kaolinite-like $(1: 1$ clay structure) composition. This may suggest an impure kaolinite or montmorillonite that is not captured in the cation subcomposition due to the relatively high sensitivity to $\mathrm{K}^{+}$in the LAAPTOF measurement. A comparison of the subcomposition $(\mathrm{Al}+\mathrm{Si}) /(\mathrm{Al}+\mathrm{Si}+\mathrm{K}+\mathrm{Na})$ obtained by SPMS and SEM (Fig. 8) demonstrates a much greater sensitivity to alkali metals in the SPMS measurement (due to low ionisation energy) than in the established filter technique. The SEM technique reports a lower $(\mathrm{Al}+\mathrm{Si}) /(\mathrm{Al}+\mathrm{Si}+\mathrm{K}+\mathrm{Na})$ ratio in the Moroccan sample (DDS01; Fig. 8a) compared to the Sahel sample (SDN02; Fig. 8c), but this is greatly exaggerated in the SPMS analysis (Fig. 8b and d) due to selective ionisation of $\mathrm{K}$ and $\mathrm{Na}$ and the matrix effect. 


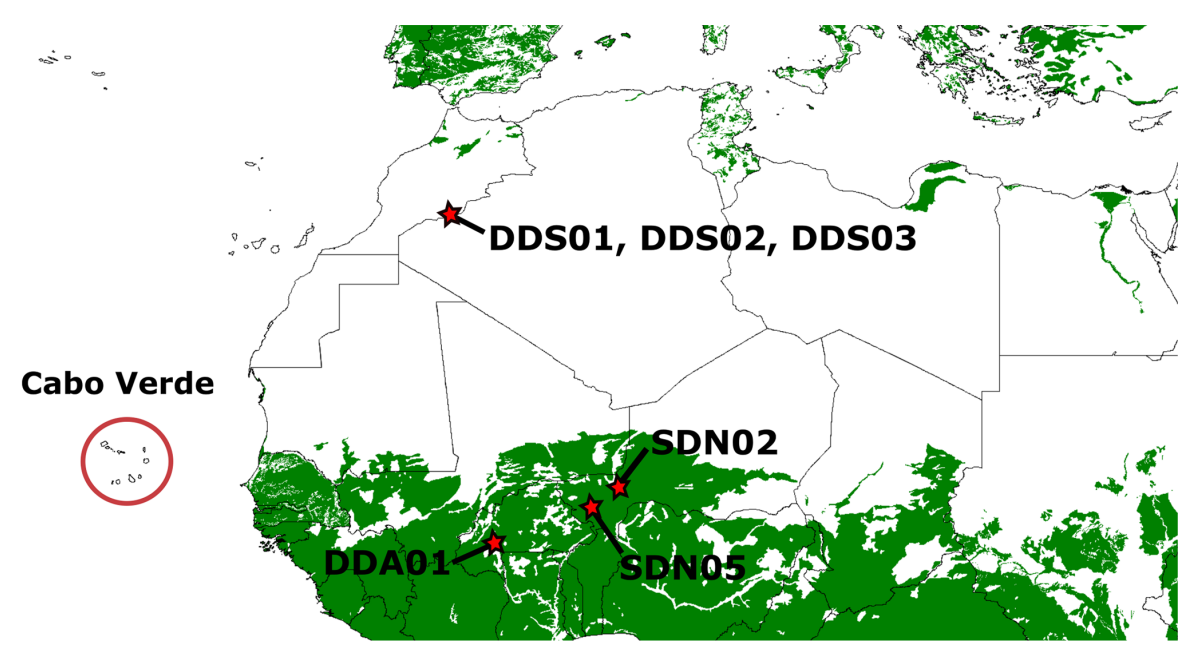

Figure 6. Sampling locations of natural soil (stars) and transported dust at Cabo Verde (circle). The green colour indicates soils that have a cation ion exchange capacity (CEC) of less than $35 \mathrm{cmol} \mathrm{kg}^{-1}$ indicating kaolinite-rich soil. This figure is produced from the Digital Soil Map of the World.

Table 1. Sampling location of natural soils for laboratory experiments.

\begin{tabular}{lll}
\hline Sample & Location & Notes \\
\hline DDS01 & $29.83773^{\circ} \mathrm{N},-5.76143^{\circ} \mathrm{E}$ & River sediments \\
DDS02 & $29.84957^{\circ} \mathrm{N},-6.01508^{\circ} \mathrm{E}$ & Hamada with large amounts of dust \\
DDS03 & $29.86202^{\circ} \mathrm{N},-6.156760^{\circ} \mathrm{E}$ & Border of dry salt/silt plain \\
SDN02 & $13.516667^{\circ} \mathrm{N}, 2.633333^{\circ} \mathrm{E}$ & Banizoumbou, Niger \\
SDN05 & $13.522203^{\circ} \mathrm{N}, 2.133011^{\circ} \mathrm{E}$ & Grand Mosque, Niamey, Niger \\
DDA01 & NA & Dano, Burkina Faso \\
\hline
\end{tabular}

NA: not available.

In general, our analysis suggests that the fine fraction of these north African soil samples consists of K-rich and Alrich clay minerals. This agrees somewhat with a comprehensive study of soil samples using many techniques by Engelbrecht et al. (2016) that concluded suspended mineral dust particles were primarily made up of two types of mineral assemblages: (i) fragments of micas, clays, oxides and ions of potassium-rich $\left(\mathrm{K}^{+}\right)$, calcium-rich $\left(\mathrm{Ca}^{+}\right)$and sodiumrich $\left(\mathrm{Na}^{+}\right)$colloids in amorphous clay-like material, and (ii) kaolinite with individual oxide mineral grains. The exception is that our measurements indicate that the potassium and sodium are retained in a $2: 1$ clay structure rather than in amorphous clay.

In order to explore the composition of potentially amorphous and feldspar matrix, we extracted particles with $\tau$ values of 0.58-0.8 into separate plots (Fig. 9). Perhaps unsurprisingly, the composition of these types of particles reflects the composition of clay particles (Fig. 7), with samples from the Sahel showing a greater loss of alkali metals due to weathering and diagenesis. It is not possible to separate felsic and amorphous material with any confidence, but it is reasonable to say that any feldspars that may be present in the
Moroccan samples are fresher (unaltered) than their counterparts from the Sahel due to the higher potassium content. It is known that K-feldspar is progressively altered to quartz and kaolinite if the potassium is removed by dissolution in the soil.

The sample that potentially has the most feldspar grains is DDS01, which shows a small number of particles with a felsic composition in the SEM EDX analysis (Fig. 5b) and may be a reflection of the river sediment containing freshly eroded rock from the Anti-Atlas mountain range. This sample also displays a distinct mode in the SPMS $\tau$ histogram in the felsic/amorphous region (Fig. 7d). In general, the SPMS crystal structure analysis in the $\tau$ histograms agrees with the SEM EDX analysis of the distribution of composition in the samples. For example, the $\tau$ histogram of DDS02 indicates a predominately illite composition which is also reported in the narrow composition distribution in the SEM EDX analysis.

\subsubsection{Internal mixing state of suspended natural soil}

Unlike the mineralogical composition, the mixing state of the natural soil samples varied quite a lot within the same PSA (Fig. 10). Sample DDS03, collected close to a salt/silt 


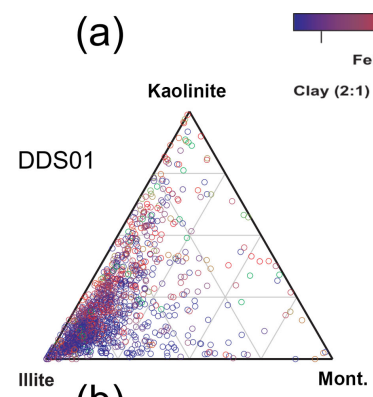

(b)

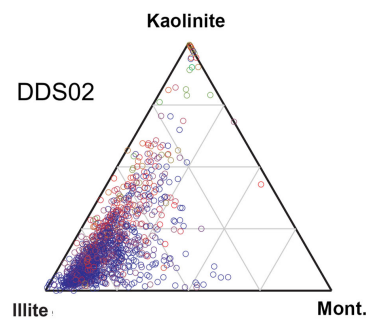

(c)

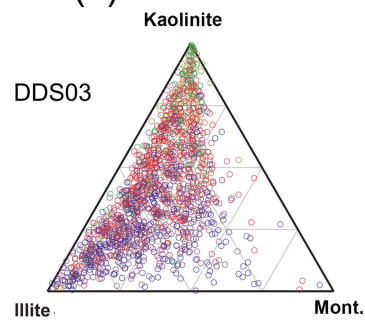

(d)

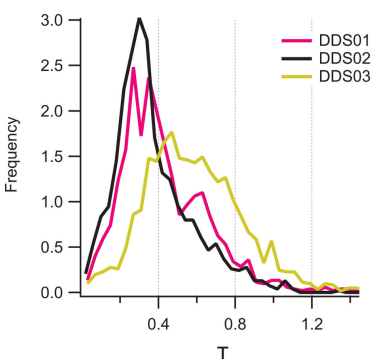

(e)

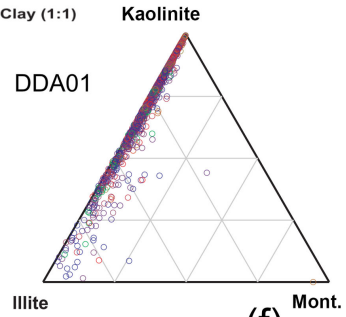

(f)

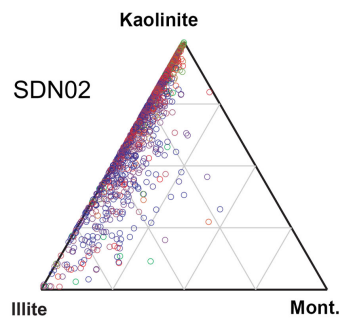

(g)

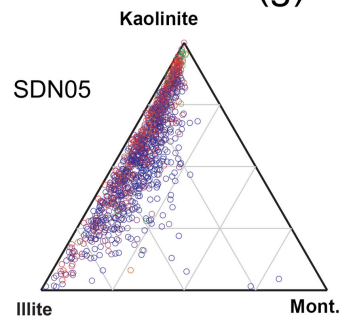

(h)

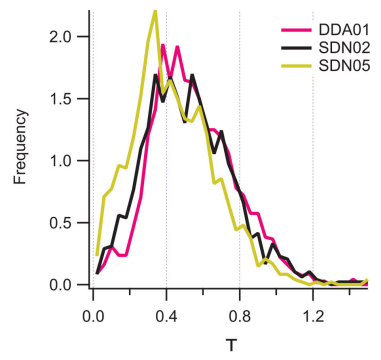

Figure 7. Subcompositional analysis of suspended natural soil samples (INUIT09) by SPMS. The ternary diagrams are referenced to the inferred kaolinite, illite, Na-montmorillonite endmembers of the clay mineral series using the $\mathrm{Al}+\mathrm{Si}, \mathrm{K}$ and $\mathrm{Na}$ ratios from reference minerals (Fig. 3). Samples from Morocco are in the left column (a, b, c) and samples from the Sahel in the right column (e, f, g). The colour function is proportional to the $\tau$ parameter as defined by the crystal structure analysis technique, so that the blue dots represent $2: 1$ clay minerals. The distribution of $\tau$ for each sample is also displayed as a histogram (d, h) (2000 particles analysed in each sample).

plain, shows a relatively high sulfate content, probably associated with evaporite deposits. The biggest difference, however, is the relative amount of org-bio internally mixed in the particles. This is further demonstrated in the histograms of the normalised org-bio content displayed in Fig. 11. Most
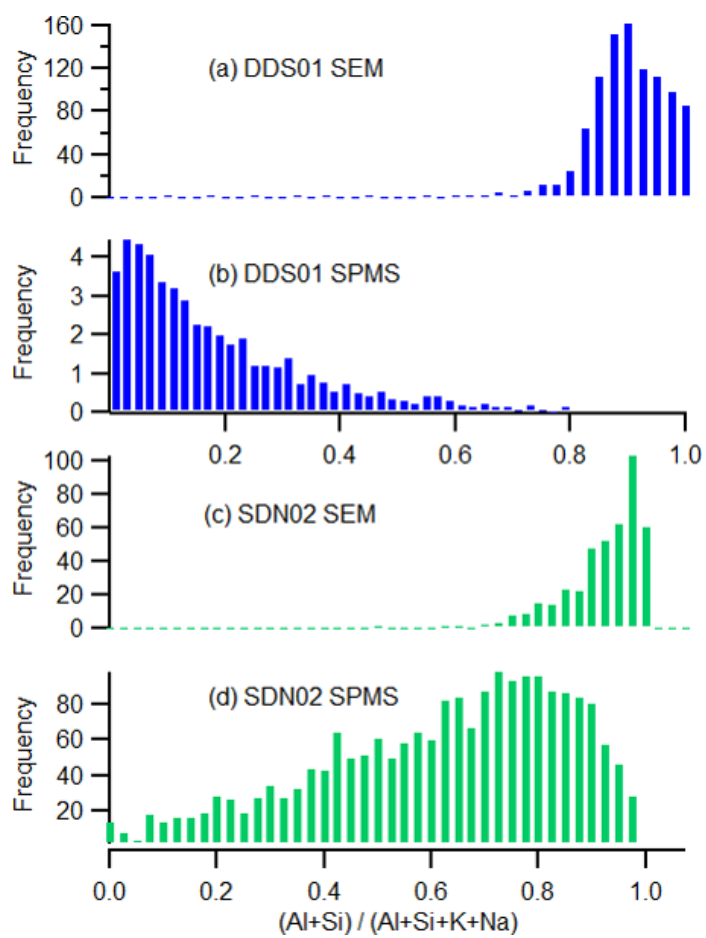

Figure 8. A comparison of the relative sensitivity of the SEM and SPMS techniques to the principal elements in silicate minerals. Histograms represent the sensitivity to alkali metals of the interstitial complex with respect to the $\mathrm{Al}$ and $\mathrm{Si}$ of the silicate structure $(\mathrm{Al}+\mathrm{Si}) /(\mathrm{Al}+\mathrm{Si}+\mathrm{K}+\mathrm{Na})$ in single particles. Moroccan soil sample DDS01 (a, b) compared to Sahelian soil sample SDN02 (c, d) using the SEM and SPMS techniques, respectively.

samples contain particles with significantly less org-bio than chlorine, but samples DDS01 and SDN02, collected from a dry river bed and agricultural land, respectively, have a number of particles where the org-bio signal is even stronger than that of chlorine, which is significant given the high electron affinity of the later. All laboratory-suspended soil samples contained a significant amount of chlorine, demonstrating that chlorine can be internally mixed with silicate particles before emission and transport. This makes the $\mathrm{Al} / \mathrm{Cl}$ ratio used by Sullivan et al. (2007b) in ambient Asian dust an unreliable measure of heterogeneous reaction of silicate with atmospheric $\mathrm{HCl}$ in ambient Saharan dust.

\subsection{The composition and transport history of transported dust (ICE-D)}

In order to examine the properties of the transported dust in the ambient measurement, the mass spectra of silicate particles were first extracted from the general aerosol population. This was achieved using the fuzzy c-means clustering supplied with the data analysis software (LAAPTOF data analysis v1.0.2). The analysis was performed on positive and negative ion spectra and on negative ion spectra only. In both 
(a)

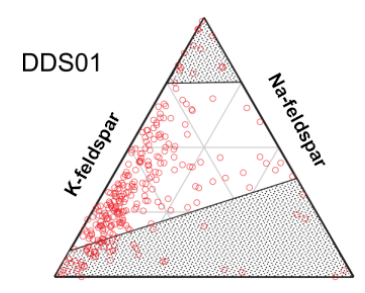

(b)

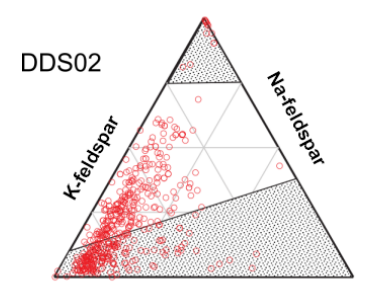

(c)

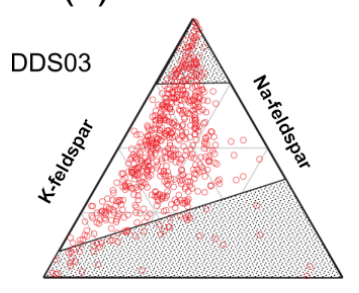

(e)

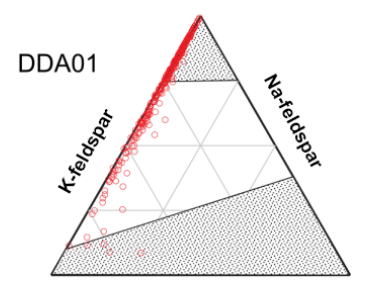

(f)

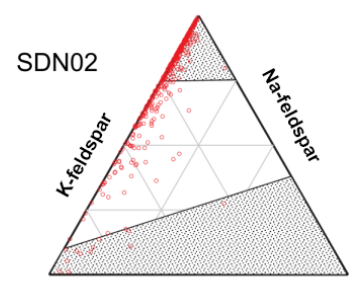

(g)

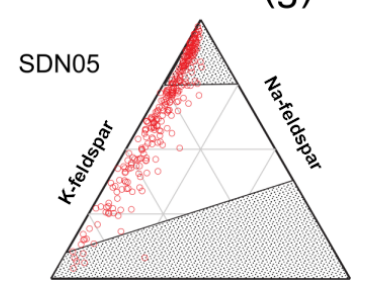

Figure 9. Subcompositional analysis of the feldspar/amorphous content in suspended natural soil samples (INUIT09) by SPMS. The felsic/amorphous fraction was selected by crystal structure analysis $(0.58<\tau<0.8)$. The ternary diagrams are referenced to the inferred $\mathrm{K}$ and $\mathrm{Na}$ endmembers of the feldspar series using the $\mathrm{Al}+\mathrm{Si}$, $\mathrm{K}$ and $\mathrm{Na}$ ratios from reference minerals (see Fig. 3). The greyed out area represents unlikely composition of feldspar as demonstrated by the reference minerals. Samples from Morocco are in the left column $(\mathbf{a}, \mathbf{b}, \mathbf{c})$ and samples from the Sahel in the right column $(\mathbf{e}, \mathbf{f}$, g).

cases, silicate and calcium classes of particles were reported along with sulfate, carbonaceous and abundant sea-salt particles. Analysis using only negative ion spectra proved more useful in the evaluation of mixing state because it was not subject to false class divisions caused by greater peak position shifting in positive ion spectra. A full description of the clustering analysis, including mass spectra of the cluster centres, is provided in Sect. S3 in the Supplement.

Averaged detection rate of the silicate and calcium particle types, as determined by the fuzzy clustering analysis, is displayed in Fig. 12a with a $1 \mathrm{~h}$ resolution. A previous comparison with an aerodynamic particle sizer indicated that the silicate particle count represented approximately $1 \%$ of the actual silicate present due to instrument function (Marsden et al., 2016). Nevertheless, the temporal evolution of the particle classes is representative and compares well to the dust

fraction of incandescent particles identified in tandem soot photometer (SP2) measurement (Liu et al., 2018).

\subsubsection{Calcium-rich particles}

Calcium carbonate $\left(\mathrm{CaCO}_{3}\right)$ is the most abundant nonsilicate material in arid soils and is expected to be a major constituent in mineral dust aerosol. However, pure calcium carbonate particles were not observed in this ambient measurement. Alkaline calcium carbonate particles are expected to readily react with acid gases in the atmosphere to form calcium salts. The reaction of calcium carbonate with nitric acid has been offered as a mechanism to explain $\mathrm{Ca}\left(\mathrm{NO}_{3}\right)_{2}$ on filters exposed to dusty environments (Krueger et al., 2004; Laskin et al., 2005; Matsuki et al., 2005; Hwang and Ro, 2006; Sobanska et al., 2012). More recently, it has been suggested that, in remote marine environments, a prevalence of $\mathrm{HCl}$ over $\mathrm{HNO}_{3}$ would favour the formation of $\mathrm{CaCl}_{2}$ as the principal calcium salt (Tobo et al., 2009; Kim and Park, 2012).

A distinct calcium chloride particle class is reported in this ambient measurement. These particles are characterised by signals of $\mathrm{Ca}^{+}(m / z 40), \mathrm{CaO}^{+}(m / z 56)$ and $\mathrm{CaCl}^{+}$ $(m / z 75,77)$ in positive ion spectra, and $\mathrm{Cl}^{-}(\mathrm{m} / z-35$, $-37)$ and $\mathrm{CaCl}_{3}^{-}(m / z, 145,147,149)$ in negative ion spectra (see Sect. S3.2 in the Supplement). The temporal evolution of this particle class is similar to that of the silicate particle class (Fig. 12a) but is very different to that of the sea-spray particles (see Sect. S3.5 in the Supplement); therefore, we conclude that it has a similar source to the silicate and probably represents calcium carbonate that has been processed in the atmosphere.

\subsubsection{Temporal evolution of the silicate particle mineralogy (ICE-D)}

In order to create a concise time series of the single-particle mineralogy for the entire time period, the silicate class of particles (previously identified by cluster analysis) was differentiated into a simple binary system of ISCM and non-ISCM using the crystal structure analysis ( $\tau$ parameter) to produce a time series of the ISCM ratio (Fig. 12b). The ISCM ratio is the number of particles which have $\tau<0.58$ divided by the number of silicate particles which have $\tau>0.58$, representing ISCM and non-ISCM (feldspar, amorphous and pure kaolinite), respectively (see Sect. 2.1.1). The average detection rates of silicate- and calcium-containing particles were combined to produce an hourly average of the ISCM, non-ISCM and calcium number fractions in mineral dust (Fig. 12c). Note that these fractions are relative to the detection efficiency of the instrument to each particle type (see Sect. 2.1), so that ratios presented here are semi-quantitative only, but the temporal evolution is representative of changes in particle composition. 

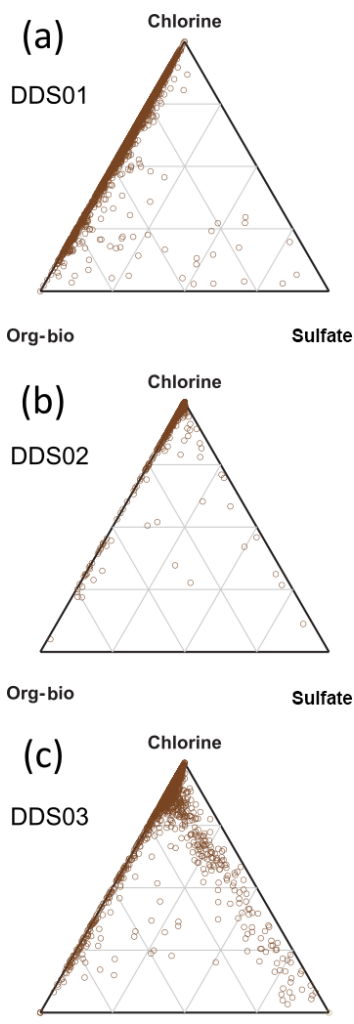

Org-bio

Sulfate
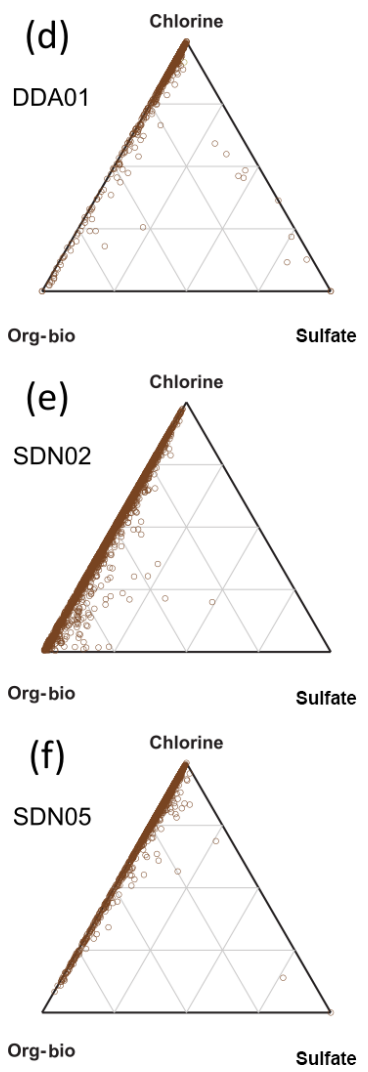

Figure 10. Subcompositional analysis of the non-silicate content in suspended natural soil samples (INUIT09) by SPMS. Ternary plots of the $\mathrm{Cl}$, organic-biological and sulfate marker peak areas in Moroccan (a, b, c) and Sahelian (c, d, e) resuspended soil dust (2000 particles analysed in each sample).

Most of the measurement period was characterised by a relatively high ISCM ratio which is generally $\gg 1$. This is consistent with continuous long-term offline measurements of elemental composition around Cabo Verde by Patey et al. (2015), who concluded that illite was the most abundant clay mineral type. However, these conditions changed 17 August when the ISCM ratio was much lower than in the previous period (ISCM ratio $<1$ ) and the fraction of calciumcontaining particle increased. We used the time series to define two dust events (D1 centred on 00:00 LT, $11 \mathrm{Au}-$ gust 2015 and D2 centred on 15:00LT, 17 August 2018) which were analysed in more detail with subcompositional analysis, using the same method applied to the soil dust samples.

Silicate dust in event D1 contained a high fraction of ISCM-type mineral composition with $2: 1$ phyllosilicate structure (blue circles in Fig. 13a), that plotted close to the illite composition in the ternary diagram, similar to that observed in Moroccan soils DDS01 and DDS02 (Fig. 7b, c). In contrast, these ISCM particles are much reduced in dust event D2, which has a higher proportion of non-ISCM (felsic or amorphous material (red circles in Fig. 13e) and shifts

away from the illite composition on the diagram. The actual mineral phase of these particles is less clear, but from the large fraction of these particle types and their central position on the ternary diagram, it would be reasonable to assume a mixed amorphous matrix. It is clear, however, that the large fraction of particles with illite matrix present in D1 is absent in D2. The potential source and transport history of these materials in these dust events is discussed in more detail after consideration of the mixing state below.

\subsection{Temporal evolution of the mixing state of silicate particles (ICE-D)}

The mixing of silicate and non-silicate within single particles may result from processes within the native soil (primary) or during atmospheric transport (secondary). The internal mixing state of transported silicate dust (ICE-D) is reported with the subcomposition chlorine - Org-bio - nitrate, similar to the treatment of suspended dust (INUIT09) in Sect. 3.1.2, except we target nitrate in ambient particles instead of sulfate because nitrate was present in low quantities in suspended soil. An increase in nitrate aerosol has previously been observed in association with air masses passing through Europe and Africa to Cabo Verde (Fomba et al., 2014), so this may be a useful indicator of the history of transported dust. The analysis of the suspended soil dust showed mineral particles in north African soils are already mixed, particularly with varying quantities of chlorine, sulfate and organic-biological material. Therefore, the internal mixing state observed in transported dust may be derived from primary or secondary sources.

In transported dust, nitrate mixing with the silicate dust was varied, with the subcomposition of nitrate markers indicating a relatively greater quantity of nitrate mixing with silicate particles during the period between the defined dust events. This showed a similar trend to the number concentration of nitrate sea-spray aerosol particle types extracted by fuzzy clustering (Sect. S3.5 in the Supplement), which suggest the particles may have coexisted in the same air mass for some period of time. There was a distinct drop in nitrate subcomposition during dust period D2 when we also measured a change in silicate mineralogy.

Although it is not possible to conclude a primary or secondary source of organic-biological mixing, we observed less variation in mixing state in the transported dust than in the laboratory-generated reference material. The number of particles whose mixing state subcomposition contained more than $20 \%$ organic-biological material (org-bio $>0.2$ ) varies with the dust concentration (Fig. 12d), and the median amount of the organic-biological marker signal is fairly stable, with the exception of a $24 \mathrm{~h}$ period following dust event D1 (Fig. 12e). This may be informative of how well mixed local sources of dust become after emission but could also be a reflection of atmospheric processing. 

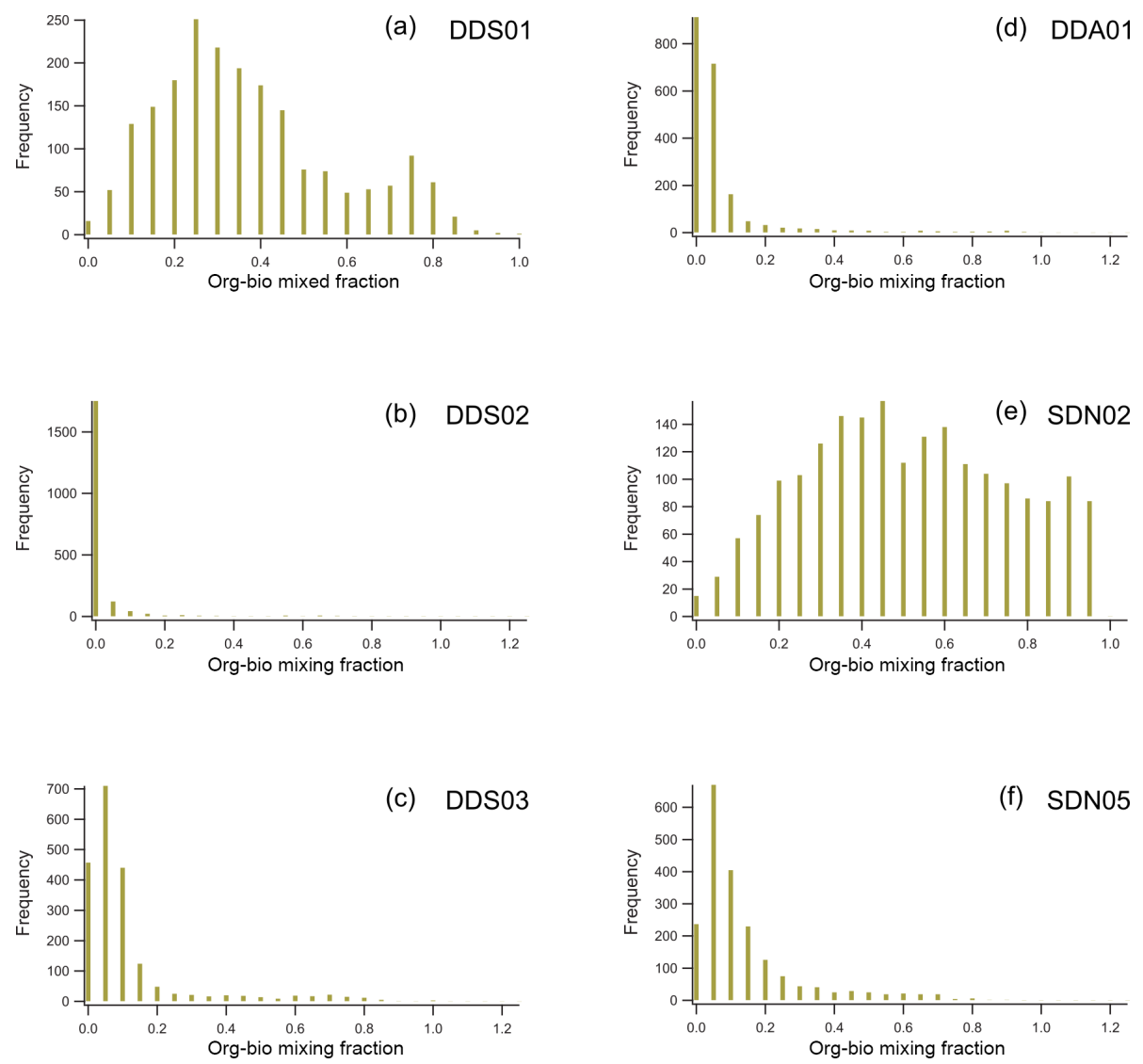

Figure 11. A comparison of the relative organic-biological content in the non-silicate portion in suspended natural soil samples (INUIT09). Histograms are of the normalised org-bio fraction in single particles of Moroccan (a, b, c) and Sahelian (d, e, f) samples.

Particle mixing is important because the efficient icenucleating properties of proteinaceous INPs can be transferred to dust particles after mixing (Augustin-Bauditz et al., 2016; O'Sullivan et al., 2016). It is interesting to note that Price et al. (2018) did not see significant variation in INP concentration in aircraft-based studies of the Saharan air layer during ICE-D, despite geographically widespread sources of that dust. The origin of the organic-biological markers $\mathrm{CN}^{-}$and $\mathrm{CNO}^{-}$in these dust particles requires further investigation. Zawadowicz et al. (2017) demonstrated a method of distinguishing between biogenic and inorganic ion signals using a different SPMS instrument (PALMS), but it is not yet proven to be transferable to other instruments' designs.

\subsection{Potential source areas and transport history}

Dust transport to Cabo Verde is controlled by the position of the Azores High pressure system, whose anticyclonic flow results in persistent north-easterly trade winds along the coast of Morocco, western Sahara and Mauritania (Carpenter et al., 2010). Dust concentrations at ground level are influenced by the dust deposition rate, which is strongly dependent on the horizontal and vertical dust distribution (Schepanski et al., 2009a). We used back-trajectory analysis, satellite observations and our measurement of dust mineralogy and mixing state to give potential source areas and transport history of two dust events observed at Cabo Verde in the summer of 2015.

Back-trajectory analysis of both dust events (D1 and D2, defined in the analysis above), shows transport in the trade winds within the marine boundary (Fig. 13c, g). Influence from the African continent is evident during D1 when some of this air mass was lofted over the Atlas Mountains, Morocco, before descending into the marine boundary layer (MBL). The high ISCM ratio we measure $(68 \%)$ is consistent with Scheuvens et al. (2013), who suggested illite/kaolinite ratio $>2$ is indicative of the PSA that comprises the northern part of the west coast of Africa and the south-eastern slopes of the Atlas Mountains. Satellite observations at the time showed a plume of dust developing in Algeria and crossing the Atlas Mountains and then above the Atlantic Ocean in the days proceeding dust event D1 (Sect. S5 in the Supplement). However, source activation observed by remote satellite is subject to errors associated with the temporal resolution of the measurement (Schepanski et al., 2012). Dust emission associated with density currents 


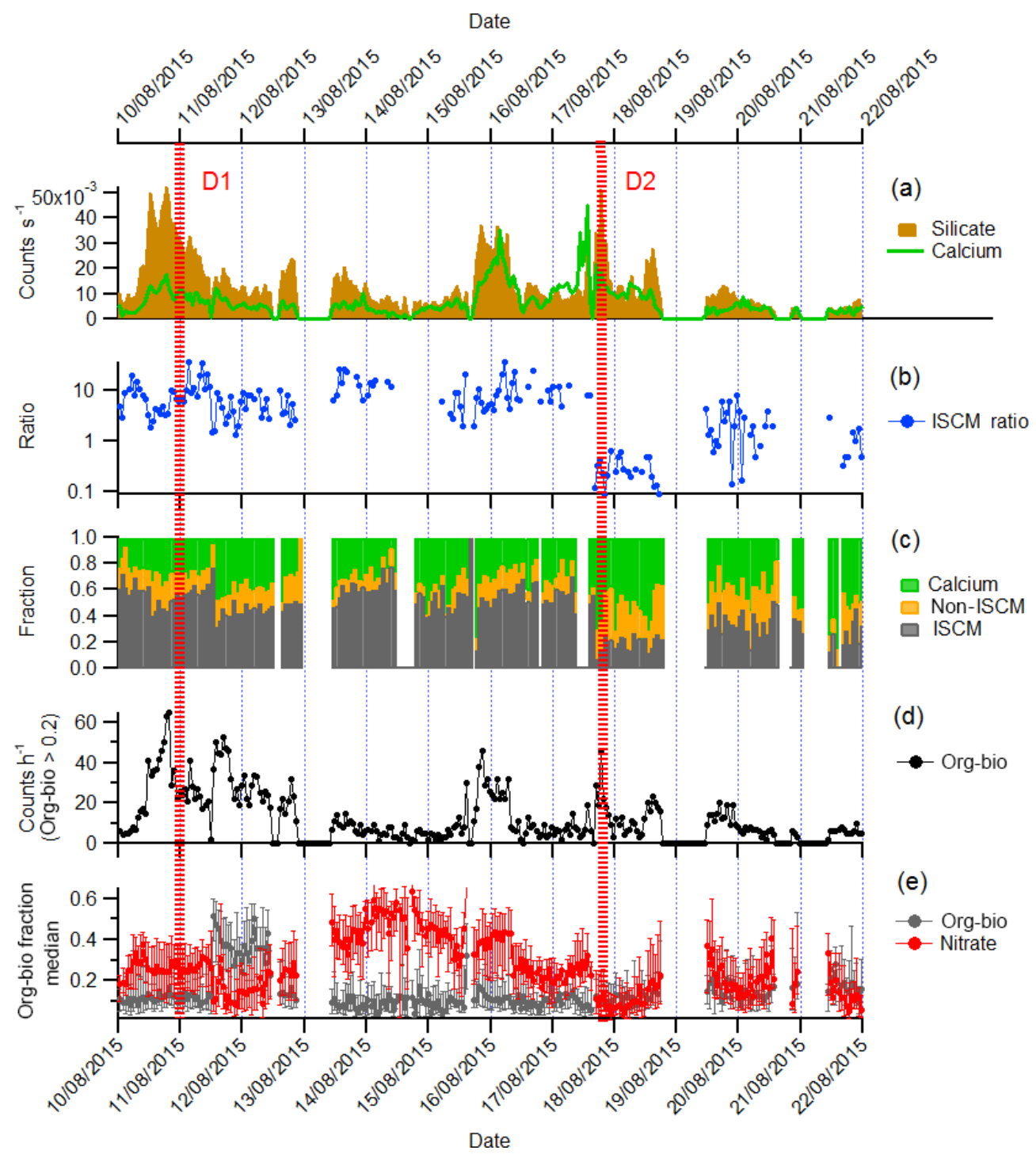

Figure 12. Time series ( $1 \mathrm{~h}$ resolution) of ambient dust properties measured at Cabo Verde during the ICE-D campaign by LAAPTOF SPMS. (a) Concentration of silicate- and calcium-rich particles (from 12698 silicate and 6837 calcium particles measured). (b) Hourly average ratio of ISCM to non-ISCM minerals (ISCM ratio) determined by crystal structure. (c) Hourly particle number fraction of calcium, ISCM and non-ISCM particles. (d) Hourly concentration of silicate particles with organic-biological subcomposition $>0.2$. (e) Hourly median org-bio and nitrate subcomposition marker quantity. Error bars are at the 25th and 75 th percentiles.

related to moist convection had been previously observed on the Sahara side of the Atlas mountain chain by Knippertz et al. (2007), where the soil mineral content is a close match to the material we report in this dust event. The Anti-Atlas Mountains were also suggested as a source of micronutrients in sediment traps in the north-east Atlantic Ocean by Chavagnac et al. (2007).

In contrast, back trajectories for D2 suggest this air mass was never lofted over Africa but came into direct contact with the coastline of Mauritania. This is a possible source of dust that could explain the relatively low ISCM content and relatively high calcium fraction which is consistent with source sediments of the Atlantic coastal basin (Moreno et al., 2006).
In offline filters collected at Praia, Cabo Verde, Kandler et al. (2011b) reported an illite/kaolinite ratio of between $1: 2$ and $1: 4$ during winter transport of dust from coastal Mauritania and Mali, respectively.

The nitrate mixing state of particles also suggests different transport pathways for the two dust events. The mixing of nitrate with silicate during and after D1 indicates contact with polluted air and is consistent with transport from the north, as reported by Salvador et al. (2016), whilst the cleaner particles in D2 indicate that no such mixing took place. An increase in the fraction of sulfate-containing sea-spray aerosol in D2 on the other hand (Sect. S3.5 in the Supplement) may be associated with organosulfur-containing compounds from 

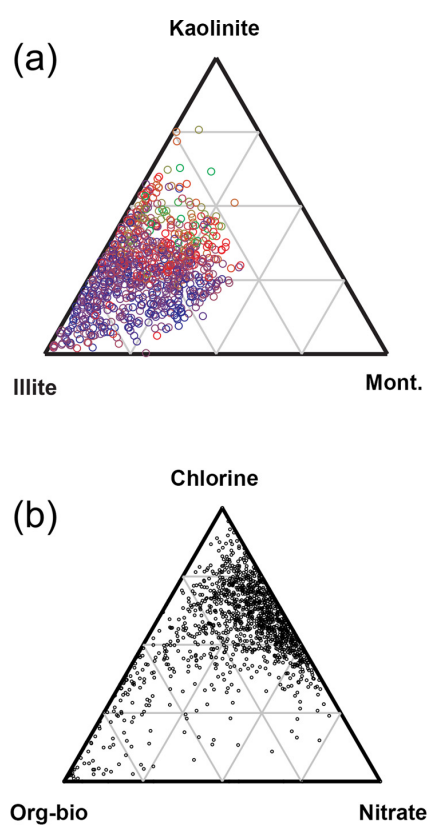

(c)
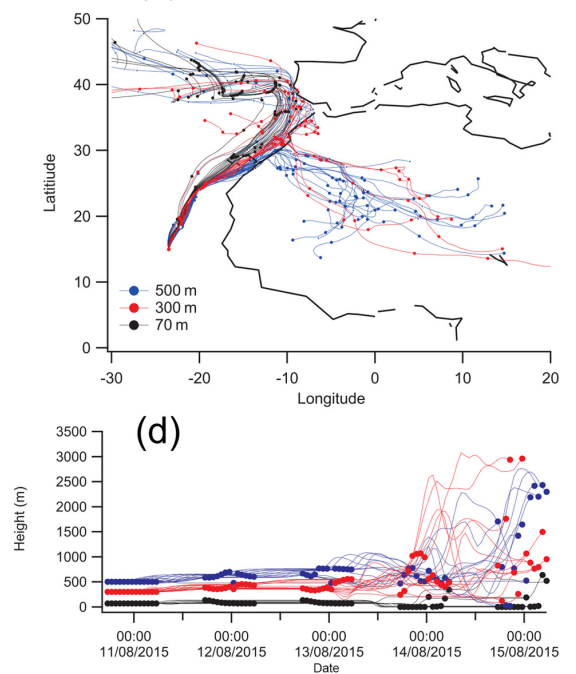

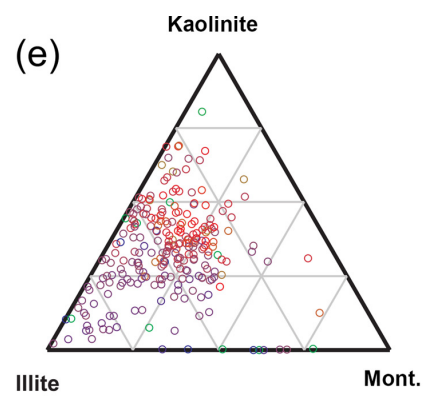

(f)

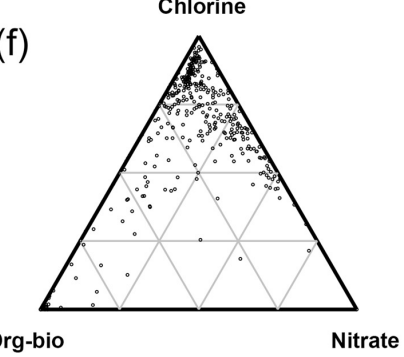

(g)

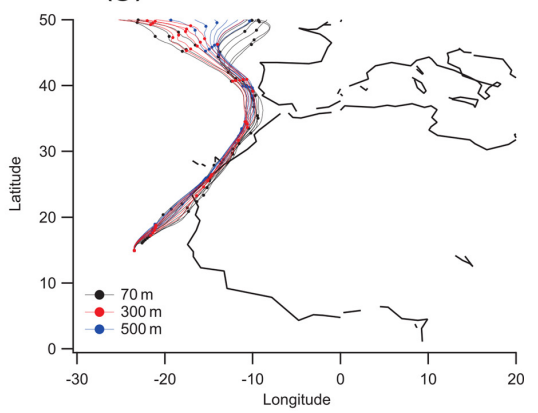

(h)

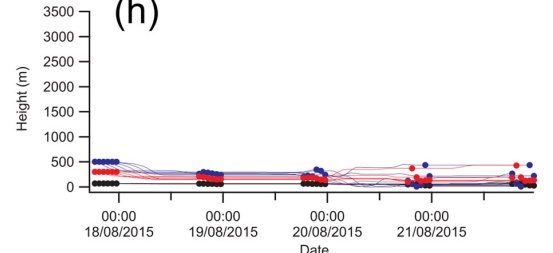

Figure 13. Analysis of the mineralogy and mixing state of dust events D1 in the left column (a-d) (1301 particles analysed) and D2 in the right column (e-f) (378 particles analysed). Mineralogical analysis by SPMS shows the high number of illite particles (blue circles) present in D1 (a) is absent in D2 (e). In addition, mixing state analysis shows a higher proportion of particles mixed with nitrate in D1 (d) than in D2 (f). Hybrid Single-Particle Lagrangian Integrated Trajectory (HYSPLIT) back-trajectory analysis suggests influence of air masses from the Sahara during D1 (c, d) and coastal Mauritania during D2 $(\mathbf{g}, \mathbf{h})$.

biogenic sources in the coastal upwelling region off the coast of Mauritania. In addition, the particle size distribution of the silicate from D2 also suggests that this dust may have been transported a relatively short distance compared to D1 (see Sect. S4 in the Supplement). The silicate from D1 has a welldefined mode at approximately $1 \mu \mathrm{m}$, which is in contrast to the broader distribution of D2 particle sizes, which extends above $2 \mu \mathrm{m}$.

Our high-resolution measurements show that the mineralogy and mixing state of dust can change on a hourly basis, suggesting that changes in dust source, transport pathways and particle composition are lost in offline data. For example, in XRD analysis of material captured in marine sediment traps of Cape Blanc, Mauritania, Friese et al. (2017) concluded that seasonal variation in mineralogy occurred due to changes in transport pathways: from long-distance transport in the SAL during summertime to local transport in the trade winds in winter. Our measurements also suggest two pathways for dust arriving at Cabo Verde that change over a much shorter time period of hours rather than months. We 
propose that, in August 2015, illite-rich dust from the NW margin of the Sahara was advected into the free troposphere and became mixed in to the MBL off the coast of Morocco before several days of transport to Cabo Verde. An eastward shift in the Azores High results in the direct entrainment of dust into the MBL from the coast of Mauritania, producing a relatively illite-poor and calcium-rich dust event in Cabo Verde on 17 August that lasted for a few hours. In all the above offline studies, filters were exposed for around 1 day, resulting in insufficient temporal resolution of the data.

\section{Conclusions}

We have presented a detailed characterisation of the mineralogy and mixing state of the fine fraction $(<2.5 \mu \mathrm{m})$ of north African mineral dust using a novel combination of subcomposition and crystal structure analysis with a single-particle mass spectrometer. Despite the fact that the technique provides incomplete coverage in terms of particle number, elemental composition and mineralogy, it was possible to detect regional differences in the mineralogy in single particles of suspended soil and ambient transported dust.

The following conclusions were made under the reasonable assumption that single particles in the fine fraction were composed of either clay minerals or feldspars/amorphous matrix, a distinction that can be realised by our novel crystal analysis technique. Although the SPMS technique has been shown to be generally non-quantitative with respect to the elemental subcomposition of pure mineral phases such as illite and K-feldspar, a semi-quantitative (relative) measurement of elemental composition can be achieved after particles are separated into mineral groups based on crystal structure. Differentiation of the mineral phase can then be made by comparison to pure mineral fingerprints from within the mineral group. This indicates the importance of particle structure in addition to particle composition in the matrix effect in SPMS.

The sensitivity of the technique to potassium, sodium and aluminum makes it particularly useful for differentiating illite (potassium-rich clay), montmorillonite (sodiumrich clay) and kaolinite (aluminum-rich clay) clay mineral assemblages. Comparison with offline SEM EDX analysis of the suspended soil confirms the observations that a composition close to illite is observed in Moroccan samples compared to a kaolinite composition in samples from the Sahel, in agreement with geology of these regions. SPMS is less effective than SEM EDX at identifying particles rich in magnesium and calcium due to suppression by the matrix effect and interference from poorly resolved peaks, but it is likely that these elements are derived from carbonates and oxides and are not strictly necessary to classify the silicate minerals. This makes the assumption that $\mathrm{Mg}, \mathrm{Fe}$ and $\mathrm{Ca}$ are of minor importance in silicate mineralogy in continental sediment, which is certainly not true on a local level. However, our measurements show it is not necessary to include these el- ements when considering the genesis and subsequent weathering history of the clay fraction in soil on a continental scale.

These results show that the SPMS and SEM EDX techniques are complementary, with SPMS providing a highresolution online indication of mineralogy and mixing state of the principal particle matrix, and SEM EDX providing semi-quantitative elemental composition of all particles, including material that the SPMS may not vaporise. In most cases, both techniques show the distribution of mineralogical composition is more continuous than clustered in distinct mineral phases, and only laboratory-suspended river sediment from the Anti-Atlas Mountains, Morocco, contained a distinct mode of fine particles with a feldspar matrix.

The detailed analysis of laboratory-suspended dust provided useful reference data for the interpretation of the origins and transport history of ambient dust in the remote North Atlantic. Although semi-quantitative in terms of particle number fractions due to number-counting bias effects associated with instrument function, the relative temporal trends are very informative. A relatively large number of illite-rich particles (ISCM ratio > 5) suggests a dust source on the NW margins of the Sahara during the summer. However, a rapid change $(<1 \mathrm{~h})$ towards a felsic/amorphous particle matrix (ISCM ratio $<1$ ) was observed in silicate particles when back trajectories suggested direct emission into the marine boundary layer from the west African coast. This episode lasted only a few hours and challenges previous findings from offline measurements that the source and composition of transported dust only change on a seasonal basis.

Internal mixing state was of some use to understanding transport history of ambient dust but must be used with caution because some degree of mixing was already present in the primary soil. However, variations in internally mixed nitrate suggested dust from the NW margins of the Sahara was deposited into the marine boundary layer after transport in the Saharan air layer. In contrast, the relative concentration of organic-biological markers did not vary significantly in transported dust but had significant local variation in suspended soil samples, making them less useful for interpreting transport pathways but potentially informative of how well mixed local sources become after emission. The primary and secondary origins of these chemical markers and how they change the physiochemical properties of dust particles require further investigation.

The combination of online mineralogy and mixing state of ambient dust has potential for resolving the complexity of dust emission, transport and deposition, but more highresolution measurements at varying distance from potential dust sources are required to fully understand the complexity of these processes. The example of transported dust provided here should also be useful for studies of ice nucleation, radiative effects and heterogeneous reactions involving mineral dust. 
Data availability. LAAPTOF soil dust characterisation data collected for the INUIT09 campaign at the AIDA facility are available at https://data.eurochamp.org/data-access (last access: 15 February 2019). Data collected during the ICE-D campaign are available from the British Atmospheric Data Centre, Centre for Environmental Data Analysis (2018, http://www.ceda.ac.uk/, last access: 15 February 2019), at the following URL: http: //catalogue.ceda.ac.uk/uuid/d7e02c75191a4515a28a208c8a069e70 (last access: 15 February 2019) (Bennett, 2015).

Supplement. The supplement related to this article is available online at: https://doi.org/10.5194/acp-19-2259-2019-supplement.

Author contributions. The document was principally written by NAM with input from RU and SEH. The INUIT09 project was devised and managed by RU and OM, with SPMS data acquired by NAM. The ICE-D field data were acquired by NAM and PIW with support from MJF, JDA and HC. Data processing was performed by NAM (SPMS) and SEH (ESEM) with support from KK. Backtrajectory analysis was done by DL and ZC.

Competing interests. The authors declare that they have no conflict of interest.

Special issue statement. This article is part of the special issue "Fifth International Workshop on Ice Nucleation (FIN)". It is not associated with a conference.

Acknowledgements. ICE-D was supported by the Natural Environment Research Council (grant number NE/M001954/1), during which Nicholas A. Marsden was supported by a $\mathrm{PhD}$ studentship (NERC M113463J). This project/work has received funding from the European Union's Horizon 2020 research and innovation programme through the EUROCHAMP-2020 Infrastructure Activity under grant agreement no. 730997. We thank the AIDA engineering and technical team for maintaining and operating the cloud chamber facility. Romy Ullrich and Ottmar Möhler acknowledge funding by the Deutsche Forschungsgemeinschaft (DFG) through the research unit INUIT (FOR 1525, project MO 668/4-2). Konrad Kandler and Stine Eriksen Hammer acknowledge financial support from the Deutsche Forschungsgemeinschaft (DFG, German Research Foundation) - 264907654, 264912134 and 416816480 (KA 2280) as well as FOR 1525.

Edited by: Barbara Ervens

Reviewed by: three anonymous referees

\section{References}

Ahern, A. T., Subramanian, R., Saliba, G., Lipsky, E. M., Donahue, N. M., and Sullivan, R. C.: Effect of secondary organic aerosol coating thickness on the real-time detection and characterization of biomass-burning soot by two particle mass spectrometers, Atmos. Meas. Tech., 9, 6117-6137, https://doi.org/10.5194/amt-96117-2016, 2016.

Ansmann, A., Petzold, A., Kandler, K., Tegen, I., Wendisch, M., Müller, D., Weinzierl, B., Müller, T., and Heintzenberg, J.: Saharan Mineral Dust Experiments SAMUM-1 and SAMUM-2: what have we learned?, Tellus B, 63, 403-429, https://doi.org/10.1111/j.1600-0889.2011.00555.x, 2011.

Atkinson, J. D., Murray, B. J., Woodhouse, M. T., Whale, T. F., Baustian, K. J., Carslaw, K. S., Dobbie, S., O'Sullivan, D., and Malkin, T. L.: The importance of feldspar for ice nucleation by mineral dust in mixed-phase clouds, Nature, 498, 355-358, https://doi.org/10.1038/nature12278, 2013.

Augustin-Bauditz, S., Wex, H., Denjean, C., Hartmann, S., Schneider, J., Schmidt, S., Ebert, M., and Stratmann, F.: Laboratorygenerated mixtures of mineral dust particles with biological substances: characterization of the particle mixing state and immersion freezing behavior, Atmos. Chem. Phys., 16, 5531-5543, https://doi.org/10.5194/acp-16-5531-2016, 2016.

Baker, A. R., Kelly, S., Biswas, K., Witt, M., and Jickells, T.: Atmospheric deposition of nutrients to the Atlantic Ocean, Geophys. Res. Lett., 30, 2-5, https://doi.org/10.1029/2003GL018518, 2003.

Baustian, K. J., Cziczo, D. J., Wise, M. E., Pratt, K. A., Kulkarni, G., Hallar, A. G., and Tolbert, M. A.: Importance of aerosol composition, mixing state, and morphology for heterogeneous ice nucleation: A combined field and laboratory approach, J. Geophys. Res., 117, D06217, https://doi.org/10.1029/2011JD016784, 2012.

Bennett, L.: UK ICE-D: atmospheric measurements dataset collection, Facility for Airborne Atmospheric Measurements, Centre for Environmental Data Analysis, available at: http://catalogue. ceda.ac.uk/uuid/d7e02c75191a4515a28a208c8a069e70 (last access: 15 February 2019), 2015.

Bhave, P. V., Allen, J. O., Morrical, B. D., Fergenson, D. P., Cass, G. R., and Prather, K. A.: A field-based approach for deterimining ATOFMS instrument sensitities to ammonium and nitrate, Environ. Sci. Technol., 36, 4868-4879, 2002.

Cahill, J. F., Suski, K., Seinfeld, J. H., Zaveri, R. A., and Prather, K. A.: The mixing state of carbonaceous aerosol particles in northern and southern California measured during CARES and CalNex 2010, Atmos. Chem. Phys., 12, 10989-11002, https://doi.org/10.5194/acp-12-10989-2012, 2012.

Caponi, L., Formenti, P., Massabó, D., Di Biagio, C., Cazaunau, M., Pangui, E., Chevaillier, S., Landrot, G., Andreae, M. O., Kandler, K., Piketh, S., Saeed, T., Seibert, D., Williams, E., Balkanski, Y., Prati, P., and Doussin, J.-F.: Spectral- and size-resolved mass absorption efficiency of mineral dust aerosols in the shortwave spectrum: a simulation chamber study, Atmos. Chem. Phys., 17, 7175-7191, https://doi.org/10.5194/acp-17-7175-2017, 2017.

Caquineau, S., Gaudichet, A., Gomes, L., and Legrand, M.: Mineralogy of Saharan dust transported over northwestern tropical Atlantic Ocean in relation to source regions, J. Geophys. Res.-Atmos., 107, 4251, https://doi.org/10.1029/2000JD000247, 2002.

Carpenter, L. J., Fleming, Z. L., Read, K. A., Lee, J. D., Moller, S. J., Hopkins, J. R., Purvis, R. M., Lewis, A. C., Müller, K., Heinold, B., Herrmann, H., Fomba, K. W., Van Pinxteren, D., Müller, C., Tegen, I., Wiedensohler, A., Müller, T., Niedermeier, 
N., Achterberg, E. P., Patey, M. D., Kozlova, E. A., Heimann, M., Heard, D. E., Plane, J. M. C., Mahajan, A., Oetjen, H., Ingham, T., Stone, D., Whalley, L. K., Evans, M. J., Pilling, M. J., Leigh, R. J., Monks, P. S., Karunaharan, A., Vaughan, S., Arnold, S. R., Tschritter, J., Pöhler, D., Frieã, U., Holla, R., Mendes, L. M., Lopez, H., Faria, B., Manning, A. J., and Wallace, D. W. R.: Seasonal characteristics of tropical marine boundary layer air measured at the cape verde atmospheric observatory, J. Atmos. Chem., 67, 87-140, https://doi.org/10.1007/s10874-011-9206-1, 2010.

Carslaw, K. S., Lee, L. A., Reddington, C. L., Pringle, K. J., Rap, A., Forster, P. M., Mann, G. W., Spracklen, D. V., Woodhouse, M. T., Regayre, L. A., and Pierce, J. R.: Large contribution of natural aerosols to uncertainty in indirect forcing, Nature, 503, 67-71, https://doi.org/10.1038/nature12674, 2013.

Chavagnac, V., Waniek, J. J., Atkin, D., Milton, J. A., Leipe, T., Green, D. R., Bahlo, R., Hayes, T. E., and Schulz-Bull, D. E.: Anti-Atlas Moroccan Chain as the source of lithogenic-derived micronutrient fluxes to the deep Northeast Atlantic Ocean, Geophys. Res. Lett., 34, 1-5, https://doi.org/10.1029/2007GL030985, 2007.

Christopoulos, C. D., Garimella, S., Zawadowicz, M. A., Möhler, O., and Cziczo, D. J.: A machine learning approach to aerosol classification for single-particle mass spectrometry, Atmos. Meas. Tech., 11, 5687-5699, https://doi.org/10.5194/amt11-5687-2018, 2018.

Claquin, T., Schulz, M., and Balkanski, Y. J.: Modeling the mineralogy of atmospheric dust sources, J. Geophys. Res., 104, 22243, https://doi.org/10.1029/1999JD900416, 1999.

Connolly, P. J., Möhler, O., Field, P. R., Saathoff, H., Burgess, R., Choularton, T., and Gallagher, M.: Studies of heterogeneous freezing by three different desert dust samples, Atmos. Chem. Phys., 9, 2805-2824, https://doi.org/10.5194/acp-9-2805-2009, 2009.

Creamean, J. M., Suski, K. J., Rosenfeld, D., Cazorla, A., Demott, P. J., Sullivan, R. C., White, A. B., Ralph, F., Minnis, P., Comstock, J. M., Tomlinson, J. M., and Prather, K. A.: Dust and Biological Aerosols, Science, 339, 1572-1578, https://doi.org/10.1126/science.1227279, 2013.

Cziczo, D. J., DeMott, P. J., Brock, C., Hudson, P. K., Jesse, B., Kreidenweis, S. M., Prenni, A. J., Schreiner, J., Thomson, D. S., and Murphy, D. M.: A Method for Single Particle Mass Spectrometry of Ice Nuclei, Aerosol Sci. Technol., 37, 460-470, https://doi.org/10.1080/02786820300976, 2003.

Cziczo, D. J., Thomson, D. S., Thompson, T. L., DeMott, P. J., and Murphy, D. M.: Particle analysis by laser mass spectrometry (PALMS) studies of ice nuclei and other low number density particles, Int. J. Mass Spectr., 258, 21-29, https://doi.org/10.1016/j.ijms.2006.05.013, 2006.

Cziczo, D. J., Froyd, K. D., Gallavardin, S. J., Moehler, O., Benz, S., Saathoff, H., and Murphy, D. M.: Deactivation of ice nuclei due to atmospherically relevant surface coatings, Environ. Res. Lett., 4, 044013, https://doi.org/10.1088/1748-9326/4/4/044013, 2009.

Dall'Osto, M., Harrison, R. M., Highwood, E. J., O’Dowd, C., Ceburnis, D., Querol, X., and Achterberg, E. P.: Variation of the mixing state of Saharan dust particles with atmospheric transport, Atmos. Environ., 44, 3135-3146, https://doi.org/10.1016/j.atmosenv.2010.05.030, 2010.
DeMott, P. J.: African dust aerosols as atmospheric ice nuclei, Geophys. Res. Lett., 30, 1732, https://doi.org/10.1029/2003GL017410, 2003.

DeMott, P. J., Prenni, A. J., Liu, X., Kreidenweis, S. M., Petters, M. D., Twohy, C. H., Richardson, M. S., Eidhammer, T., and Rogers, D. C.: Predicting global atmospheric ice nuclei distributions and their impacts on climate, P. Natl. Acad. Sci. USA, 107, 11217-22, https://doi.org/10.1073/pnas.0910818107, 2010.

Di Biagio, C., Formenti, P., Balkanski, Y., Caponi, L., Cazaunau, M., Pangui, E., Journet, E., Nowak, S., Caquineau, S., Andreae, M. O., Kandler, K., Saeed, T., Piketh, S., Seibert, D., Williams, E., and Doussin, J.-F.: Global scale variability of the mineral dust long-wave refractive index: a new dataset of in situ measurements for climate modeling and remote sensing, Atmos. Chem. Phys., 17, 1901-1929, https://doi.org/10.5194/acp17-1901-2017, 2017.

Doherty, O. M., Riemer, N., and Hameed, S.: Saharan mineral dust transport into the Caribbean: Observed atmospheric controls and trends, J. Geophys. Res.-Atmos., 113, 1-10, https://doi.org/10.1029/2007JD009171, 2008.

Dunion, J. P. and Marron, C. S.: A reexamination of the Jordan mean tropical sounding based on awareness of the Saharan air layer: Results from 2002, J. Climate, 21, 5242-5253, https://doi.org/10.1175/2008JCLI1868.1, 2008.

Engelbrecht, J. P., Moosmüller, H., Pincock, S., Jayanty, R. K. M., Lersch, T., and Casuccio, G.: Technical note: Mineralogical, chemical, morphological, and optical interrelationships of mineral dust re-suspensions, Atmos. Chem. Phys., 16, 10809-10830, https://doi.org/10.5194/acp-16-10809-2016, 2016.

Eriksen Hammer, S., Mertes, S., Schneider, J., Ebert, M., Kandler, K., and Weinbruch, S.: Composition of ice particle residuals in mixed-phase clouds at Jungfraujoch (Switzerland): enrichment and depletion of particle groups relative to total aerosol, Atmos. Chem. Phys., 18, 13987-14003, https://doi.org/10.5194/acp-1813987-2018, 2018.

Evan, A. T., Flamant, C., Fiedler, S., and Doherty, O.: An analysis of aeolian dust in climate models, Geophys. Res. Lett., 41, 59966001, https://doi.org/10.1002/2014GL060545, 2014.

Fitzgerald, E., Ault, A. P., Zauscher, M. D., Mayol-Bracero, O. L., and Prather, K. A.: Comparison of the mixing state of long-range transported Asian and African mineral dust, Atmos. Environ., 115, 19-25, https://doi.org/10.1016/j.atmosenv.2015.04.031, 2015.

Fomba, K. W., Müller, K., van Pinxteren, D., Poulain, L., van Pinxteren, M., and Herrmann, H.: Long-term chemical characterization of tropical and marine aerosols at the Cape Verde Atmospheric Observatory (CVAO) from 2007 to 2011, Atmos. Chem. Phys., 14, 8883-8904, https://doi.org/10.5194/acp-148883-2014, 2014.

Formenti, P., Schütz, L., Balkanski, Y., Desboeufs, K., Ebert, M., Kandler, K., Petzold, A., Scheuvens, D., Weinbruch, S., and Zhang, D.: Recent progress in understanding physical and chemical properties of African and Asian mineral dust, Atmos. Chem. Phys., 11, 8231-8256, https://doi.org/10.5194/acp11-8231-2011, 2011.

Formenti, P., Caquineau, S., Desboeufs, K., Klaver, A., Chevaillier, S., Journet, E., and Rajot, J. L.: Mapping the physicochemical properties of mineral dust in western Africa: miner- 
alogical composition, Atmos. Chem. Phys., 14, 10663-10686, https://doi.org/10.5194/acp-14-10663-2014, 2014.

Friese, C. A., van Hateren, J. A., Vogt, C., Fischer, G., and Stuut, J.B. W.: Seasonal provenance changes in present-day Saharan dust collected in and off Mauritania, Atmos. Chem. Phys., 17, 1016310193, https://doi.org/10.5194/acp-17-10163-2017, 2017.

Gallavardin, S. J., Froyd, K. D., Lohmann, U., Moehler, O., Murphy, D. M., and Cziczo, D. J.: Single Particle Laser Mass Spectrometry Applied to Differential Ice Nucleation Experiments at the AIDA Chamber, Aerosol Sci. Technol., 42, 773-791, https://doi.org/10.1080/02786820802339538, 2008.

Gaston, C. J., Quinn, P. K., Bates, T. S., Gilman, J. B., Bon, D. M., Kuster, W. C., and Prather, K. A.: The impact of shipping, agricultural, and urban emissions on single particle chemistry observed aboard the R/V Atlantis during CalNex, J. Geophys. Res.Atmos., 118, 5003-5017, https://doi.org/10.1002/jgrd.50427, 2013.

Gemayel, R., Hellebust, S., Temime-Roussel, B., Hayeck, N., Van Elteren, J. T., Wortham, H., and Gligorovski, S.: The performance and the characterization of laser ablation aerosol particle time-of-flight mass spectrometry (LAAP-ToF-MS), Atmos. Meas. Tech., 9, 1947-1959, https://doi.org/10.5194/amt-9-19472016, 2016.

Glaccum, R. A. and Prospero, J. M.: Saharan aerosols over the tropical North Atlantic - Mineralogy, Mar. Geol., 37, 295-321, https://doi.org/10.1016/0025-3227(80)90107-3, 1980.

Griffin, D. W.: Atmospheric movement of microorganisms in clouds of desert dust and implications for human health, Clin. Microbiol. Rev., 20, 459-77, https://doi.org/10.1128/CMR.00039-06, 2007.

Gross, D. S., Gälli, M. E., Silva, P. J., and Prather, K. A.: Relative sensitivity factors for alkali metal and ammonium cations in single-particle aerosol time-of-flight mass spectra, Anal. Chem., 72, 416-22, 2000.

Gross, D. S., Atlas, R., Rzeszotarski, J., Turetsky, E., Christensen, J., Benzaid, S., Olson, J., Smith, T., Steinberg, L., and Sulman, J.: Environmental chemistry through intelligent atmospheric data analysis, Environ. Model. Softw., 25, 760-769, https://doi.org/10.1016/j.envsoft.2009.12.001, 2010.

Harrison, A. D., Whale, T. F., Carpenter, M. A., Holden, M. A., Neve, L., O'Sullivan, D., Vergara Temprado, J., and Murray, B. J.: Not all feldspars are equal: a survey of ice nucleating properties across the feldspar group of minerals, Atmos. Chem. Phys., 16, 10927-10940, https://doi.org/10.5194/acp-16-109272016, 2016.

Hatch, L. E., Pratt, K. A., Huffman, J. A., Jimenez, J. L., and Prather, K. A.: Impacts of Aerosol Aging on Laser Desorption/Ionization in Single-Particle Mass Spectrometers, Aerosol Sci. Technol., 48, 1050-1058, https://doi.org/10.1080/02786826.2014.955907, 2014.

Heinold, B., Knippertz, P., Marsham, J. H., Fiedler, S., Dixon, N. S., Schepanski, K., Laurent, B., and Tegen, I.: The role of deep convection and nocturnal low-level jets for dust emission in summertime West Africa: Estimates from convectionpermitting simulations, J. Geophys. Res.-Atmos., 118, 43854400, https://doi.org/10.1002/jgrd.50402, 2013.

Hinz, K.-P., Erdmann, N., Grüning, C., and Spengler, B.: Comparative parallel characterization of particle populations with two mass spectrometric systems LAM-
PAS 2 and SPASS, Int. J. Mass Spectr., 258, 151-166, https://doi.org/10.1016/j.ijms.2006.09.008, 2006.

Hiranuma, N., Augustin-Bauditz, S., Bingemer, H., Budke, C., Curtius, J., Danielczok, A., Diehl, K., Dreischmeier, K., Ebert, M., Frank, F., Hoffmann, N., Kandler, K., Kiselev, A., Koop, T., Leisner, T., Möhler, O., Nillius, B., Peckhaus, A., Rose, D., Weinbruch, S., Wex, H., Boose, Y., DeMott, P. J., Hader, J. D., Hill, T. C. J., Kanji, Z. A., Kulkarni, G., Levin, E. J. T., McCluskey, C. S., Murakami, M., Murray, B. J., Niedermeier, D., Petters, M. D., O'Sullivan, D., Saito, A., Schill, G. P., Tajiri, T., Tolbert, M. A., Welti, A., Whale, T. F., Wright, T. P., and Yamashita, K.: A comprehensive laboratory study on the immersion freezing behavior of illite NX particles: a comparison of 17 ice nucleation measurement techniques, Atmos. Chem. Phys., 15, 2489-2518, https://doi.org/10.5194/acp-15-2489-2015, 2015.

Hoose, C. and Möhler, O.: Heterogeneous ice nucleation on atmospheric aerosols: a review of results from laboratory experiments, Atmos. Chem. Phys., 12, 9817-9854, https://doi.org/10.5194/acp-12-9817-2012, 2012.

Hwang, H. J. and Ro, C. U.: Direct observation of nitrate and sulfate formations from mineral dust and sea-salts using low-Z particle electron probe X-ray microanalysis, Atmos. Environ., 40, 3869 3880, https://doi.org/10.1016/j.atmosenv.2006.02.022, 2006.

Jeong, G. Y. and Chun, Y.: Nanofiber calcite in Asian dust and its atmospheric roles, Geophys. Res. Lett., 33, 1-5, https://doi.org/10.1029/2006GL028280, 2006.

Jeong, G. Y. and Nousiainen, T.: TEM analysis of the internal structures and mineralogy of Asian dust particles and the implications for optical modeling, Atmos. Chem. Phys., 14, 7233-7254, https://doi.org/10.5194/acp-14-7233-2014, 2014.

Jeong, G. Y., Park, M. Y., Kandler, K., Nousiainen, T., and Kemppinen, O.: Mineralogical properties and internal structures of individual fine particles of Saharan dust, Atmos. Chem. Phys., 16, 12397-12410, https://doi.org/10.5194/acp-16-12397-2016, 2016.

Jickells, T. D., An, Z. S., Andersen, K. K., Baker, A. R., Bergametti, C., Brooks, N., Cao, J. J., Boyd, P. W., Duce, R. A., Hunter, K. A., Kawahata, H., Kubilay, N., LaRoche, J., Liss, P. S., Mahowald, N., Prospero, J. M., Ridgwell, A. J., Tegen, I., and Torres, R.: Global iron connections between desert dust, ocean biogeochemistry, and climate, Science, 308, 67-71, https://doi.org/10.1126/science.1105959, 2005.

Journet, E., Balkanski, Y., and Harrison, S. P.: A new data set of soil mineralogy for dust-cycle modeling, Atmos. Chem. Phys., 14, 3801-3816, https://doi.org/10.5194/acp-14-3801-2014, 2014.

Kandler, K., Benker, N., Bundke, U., Cuevas, E., Ebert, M., Knippertz, P., Rodríguez, S., Schütz, L., and Weinbruch, S.: Chemical composition and complex refractive index of Saharan Mineral Dust at Izaña, Tenerife (Spain) derived by electron microscopy, Atmos. Environ., 41, 8058-8074, https://doi.org/10.1016/j.atmosenv.2007.06.047, 2007.

Kandler, K., Schütz, L., Deutscher, C., Ebert, M., Hofmann, H., Jäckel, S., Jaenicke, R., Knippertz, P., Lieke, K., Massling, A., Petzold, A., Schladitz, A., Weinzierl, B., Wiedensohler, A., Zorn, S., and Weinbruch, S.: Size distribution, mass concentration, chemical and mineralogical composition and derived optical parameters of the boundary layer aerosol at Tinfou, Morocco, during SAMUM 2006, Tellus B, 61, 32-50, https://doi.org/10.1111/j.1600-0889.2008.00385.x, 2009. 
Kandler, K., Lieke, K., Benker, N., Emmel, C., Küpper, M., MüllerEbert, D., Ebert, M., Scheuvens, D., Schladitz, A., Schütz, L., and Weinbruch, S.: Electron microscopy of particles collected at Praia, Cape Verde, during the Saharan Mineral Dust Experiment: particle chemistry, shape, mixing state and complex refractive index, Tellus B, 63, 475-496, https://doi.org/10.1111/j.16000889.2011.00550.x, 2011a.

Kandler, K., Schütz, L., Jackel, S., Lieke, K., Emmel, C., MüllerEbert, D., Ebert, M., Scheuvens, D., Schladitz, A., Šegvic, B., Wiedensohler, A., and Weinbruch, S.: Ground-based off-line aerosol measurements at Praia, Cape Verde, during the Saharan Mineral Dust Experiment: Microphysical properties and mineralogy, Tellus B, 63, 459-474, https://doi.org/10.1111/j.16000889.2011.00546.x, 2011b.

Kaufman, Y. J., Koren, I., Remer, L. A., Tanré, D., Ginoux, P., and Fan, S.: Dust transport and deposition observed from the Terra-Moderate Resolution Imaging Spectroradiometer (MODIS) spacecraft over the Atlantic Ocean, J. Geophys. Res.-Atmos., 110, 1-16, https://doi.org/10.1029/2003JD004436, 2005.

Kemppinen, O., Nousiainen, T., and Jeong, G. Y.: Effects of dust particle internal structure on light scattering, Atmos. Chem. Phys., 15, 12011-12027, https://doi.org/10.5194/acp-15-120112015, 2015.

Kim, J.-S. and Park, K.: Atmospheric Aging of Asian Dust Particles During Long Range Transport, Aerosol Sci. Technol., 46, 913924, https://doi.org/10.1080/02786826.2012.680984, 2012.

Knippertz, P. and Todd, M. C.: Mineral dust aerosols over the Sahara: Meteorological controls on emission and transport and implications for modeling, Rev. Geophys., 50, RG1007, https://doi.org/10.1029/2011RG000362, 2012.

Knippertz, P., Deutscher, C., Kandler, K., Müller, T., Schulz, O., and Schütz, L.: Dust mobilization due to density currents in the Atlas region: Observations from the Saharan Mineral Dust Experiment 2006 field campaign, J. Geophys. Res.-Atmos., 112, 1-14, https://doi.org/10.1029/2007JD008774, 2007.

Kok, J. F., Ward, D. S., Mahowald, N. M., and Evan, A. T.: Global and regional importance of the direct dust-climate feedback, Nat. Commun., 9, https://doi.org/10.1038/s41467-017-02620-y, 2018.

Krueger, B. J., Grassian, V. H., Cowin, J. P., and Laskin, A.: Heterogeneous chemistry of individual mineral dust particles from different dust source regions: The importance of particle mineralogy, Atmos. Environ., 38, 6253-6261, https://doi.org/10.1016/j.atmosenv.2004.07.010, 2004.

Laskin, A., Iedema, M. J., Ichkovich, A., Graber, E. R., Taraniuk, I., and Rudich, Y.: Direct observation of completely processed calcium carbonate dust particles, Faraday Discuss., 130, 453-468, https://doi.org/10.1039/b417366j, 2005.

Liu, D., Taylor, J. W., Crosier, J., Marsden, N., Bower, K. N., Lloyd, G., Ryder, C. L., Brooke, J. K., Cotton, R., Marenco, F., Blyth, A., Cui, Z., Estelles, V., Gallagher, M., Coe, H., and Choularton, T. W.: Aircraft and ground measurements of dust aerosols over the west African coast in summer 2015 during ICE-D and AER-D, Atmos. Chem. Phys., 18, 3817-3838, https://doi.org/10.5194/acp-18-3817-2018, 2018.

Marsden, N., Flynn, M. J., Taylor, J. W., Allan, J. D., and Coe, H.: Evaluating the influence of laser wavelength and detection stage geometry on optical detection efficiency in a single- particle mass spectrometer, Atmos. Meas. Tech., 9, 6051-6068, https://doi.org/10.5194/amt-9-6051-2016, 2016.

Marsden, N. A., Flynn, M. J., Allan, J. D., and Coe, H.: Online differentiation of mineral phase in aerosol particles by ion formation mechanism using a LAAP-TOF singleparticle mass spectrometer, Atmos. Meas. Tech., 11, 195-213, https://doi.org/10.5194/amt-11-195-2018, 2018.

Matsuki, A., Iwasaka, Y., Shi, G., Zhang, D., Trochkine, D., Yamada, M., Yoon-Suk, K., Chen, B., Nagatani, T., Miyazawa, T., Nagatani, M., and Nakata, H.: Morphological and chemical modification of mineral dust: Observational insight into the heterogeneous uptake of acidic gases, Geophys. Res. Lett., 32, 1-4, https://doi.org/10.1029/2005GL024176, 2005.

Möhler, O., Benz, S., Saathoff, H., Schnaiter, M., Wagner, R., Schneider, J., Walter, S., Ebert, V., and Wagner, S.: The effect of organic coating on the heterogeneous ice nucleation efficiency of mineral dust aerosols, Environ. Res. Lett., 3, 025007, https://doi.org/10.1088/1748-9326/3/2/025007, 2008.

Moreno, T., Querol, X., Castillo, S., Alastuey, A., Cuevas, E., Herrmann, L., Mounkaila, M., Elvira, J., and Gibbons, W.: Geochemical variations in aeolian mineral particles from the Sahara-Sahel Dust Corridor, Chemosphere, 65, 261-270, https://doi.org/10.1016/j.chemosphere.2006.02.052, 2006.

Murphy, D. M.: The design of single particle laser mass spectrometers, Mass Spectr. Rev., 26, 150-165, https://doi.org/10.1002/mas, 2007.

Nickovic, S., Vukovic, A., Vujadinovic, M., Djurdjevic, V., and Pejanovic, G.: Technical Note: High-resolution mineralogical database of dust-productive soils for atmospheric dust modeling, Atmos. Chem. Phys., 12, 845-855, https://doi.org/10.5194/acp12-845-2012, 2012.

Niedermeier, D., Shaw, R. A., Hartmann, S., Wex, H., Clauss, T., Voigtländer, J., and Stratmann, F.: Heterogeneous ice nucleation: exploring the transition from stochastic to singular freezing behavior, Atmos. Chem. Phys., 11, 8767-8775, https://doi.org/10.5194/acp-11-8767-2011, 2011.

Nousiainen, T., Zubko, E., Niemi, J. V., Kupiainen, K., Lehtinen, M., Muinonen, K., and Videen, G.: Single-scattering modeling of thin, birefringent mineral-dust flakes using the discretedipole approximation, J. Geophys. Res.-Atmos., 114, 1-12, https://doi.org/10.1029/2008JD011564, 2009.

O'Sullivan, D., Murray, B. J., Ross, J. F., and Webb, M. E.: The adsorption of fungal ice-nucleating proteins on mineral dusts: a terrestrial reservoir of atmospheric ice-nucleating particles, Atmos. Chem. Phys., 16, 7879-7887, https://doi.org/10.5194/acp16-7879-2016, 2016.

Patey, M. D., Achterberg, E. P., Rijkenberg, M. J., and Pearce, R.: Aerosol time-series measurements over the tropical Northeast Atlantic Ocean: Dust sources, elemental composition and mineralogy, Mar. Chem., 174, 103-119, https://doi.org/10.1016/j.marchem.2015.06.004, 2015.

Pawlowsky-Glahn, V. and Egozcue, J. J.: Compositional data and their analysis: an introduction, Geological Society, London, Special Publications, 264, 1-10, https://doi.org/10.1144/GSL.SP.2006.264.01.01, 2006.

Peckhaus, A., Kiselev, A., Hiron, T., Ebert, M., and Leisner, T.: A comparative study of K-rich and $\mathrm{Na} / \mathrm{Ca}$-rich feldspar icenucleating particles in a nanoliter droplet freezing assay, Atmos. 
Chem. Phys., 16, 11477-11496, https://doi.org/10.5194/acp-1611477-2016, 2016.

Perlwitz, J. P., Pérez García-Pando, C., and Miller, R. L.: Predicting the mineral composition of dust aerosols - Part 1: Representing key processes, Atmos. Chem. Phys., 15, 11593-11627, https://doi.org/10.5194/acp-15-11593-2015, 2015a.

Perlwitz, J. P., Pérez García-Pando, C., and Miller, R. L.: Predicting the mineral composition of dust aerosols - Part 2: Model evaluation and identification of key processes with observations, Atmos. Chem. Phys., 15, 11629-11652, https://doi.org/10.5194/acp-15-11629-2015, 2015b.

Pratt, K. A., DeMott, P. J., French, J. R., Wang, Z., Westphal, D. L., Heymsfield, A. J., Twohy, C. H., Prenni, A. J., and Prather, K. A.: In situ detection of biological particles in cloud ice-crystals, Nat. Geosci., 2, 398-401, https://doi.org/10.1038/ngeo521, 2009.

Price, H. C., Baustian, K. J., McQuaid, J. B., Blyth, A., Bower, K. N., Choularton, T., Cotton, R. J., Cui, Z., Field, P. R., Gallagher, M., Hawker, R., Merrington, A., Miltenberger, A., Neely, R. R., Parker, S. T., Rosenberg, P. D., Taylor, J. W., Trembath, J., Vergara-Temprado, J., Whale, T. F., Wilson, T. W., Young, G., and Murray, B. J.: Atmospheric Ice-Nucleating Particles in the Dusty Tropical Atlantic, J. Geophys. Res.-Atmos., 123, 21752193, https://doi.org/10.1002/2017JD027560, 2018.

Rebotier, T. P. and Prather, K. A.: Aerosol time-of-flight mass spectrometry data analysis: a benchmark of clustering algorithms, Anal. Chim. Acta, 585, 38-54, https://doi.org/10.1016/j.aca.2006.12.009, 2007.

Reilly, P. T. A., Lazar, A. C., Gieray, R. A., Whitten, W. B., and Ramsey, J. M.: The Elucidation of ChargeTransfer-Induced Matrix Effects in Environmental Aerosols Via Real-Time Aerosol Mass Spectral Analysis of Individual Airborne Particles, Aerosol Sci. Technol., 33, 135-152, https://doi.org/10.1080/027868200410895, 2000.

Reinard, M. S. and Johnston, M. V.: Ion formation mechanism in laser desorption ionization of individual nanoparticles, J. Am. Soc. Mass Spectr., 19, 389-99, https://doi.org/10.1016/j.jasms.2007.11.017, 2008.

Reitz, P., Spindler, C., Mentel, T. F., Poulain, L., Wex, H., Mildenberger, K., Niedermeier, D., Hartmann, S., Clauss, T., Stratmann, F., Sullivan, R. C., DeMott, P. J., Petters, M. D., Sierau, B., and Schneider, J.: Surface modification of mineral dust particles by sulphuric acid processing: implications for ice nucleation abilities, Atmos. Chem. Phys., 11, 7839-7858, https://doi.org/10.5194/acp-11-7839-2011, 2011.

Ro, C. U., Hwang, H., Kim, H., Chun, Y., and Van Grieken, R.: Single-particle characterization of four "Asian Dust" samples collected in Korea, using low-Z particle electron probe X-ray microanalysis, Environ. Sci. Technol., 39, 1409-1419, https://doi.org/10.1021/es049772b, 2005.

Rosenfeld, D., Rudich, Y., and Lahav, R.: Desert dust suppressing precipitation: a possible desertification feedback loop, P. Natl. Acad. Sci. USA, 98, 5975-80, https://doi.org/10.1073/pnas.101122798, 2001.

Ryder, C. L., Highwood, E. J., Lai, T. M., Sodemann, H., and Marsham, J. H.: Impact of atmospheric transport on the evolution of microphysical and optical properties of Saharan dust, Geophys. Res. Lett., 40, 2433-2438, https://doi.org/10.1002/grl.50482, 2013.
Salvador, P., Almeida, S. M., Cardoso, J., Almeida-Silva, M., Nunes, T., Cerqueira, M., Alves, C., Reis, M. A., Chaves, P. C., Artíñano, B., and Pio, C.: Composition and origin of $\mathrm{PM}_{10}$ in Cape Verde: Characterization of longrange transport episodes, Atmos. Environ., 127, 326-339, https://doi.org/10.1016/j.atmosenv.2015.12.057, 2016.

Scanza, R. A., Mahowald, N., Ghan, S., Zender, C. S., Kok, J. F., Liu, X., Zhang, Y., and Albani, S.: Modeling dust as component minerals in the Community Atmosphere Model: development of framework and impact on radiative forcing, Atmos. Chem. Phys., 15, 537-561, https://doi.org/10.5194/acp-15-537-2015, 2015.

Schepanski, K., Tegen, I., and Macke, A.: Saharan dust transport and deposition towards the tropical northern Atlantic, Atmos. Chem. Phys., 9, 1173-1189, https://doi.org/10.5194/acp-9-11732009, 2009a.

Schepanski, K., Tegen, I., Todd, M. C., Heinold, B., Bönisch, G., Laurent, B., and Macke, A.: Meteorological processes forcing Saharan dust emission inferred from MSG-SEVIRI observations of subdaily dust source activation and numerical models, J. Geophys. Res.-Atmos., 114, 1-18, https://doi.org/10.1029/2008JD010325, 2009b.

Schepanski, K., Tegen, I., and Macke, A.: Comparison of satellite based observations of Saharan dust source areas, Remote Sens. Environ., 123, 90-97, https://doi.org/10.1016/j.rse.2012.03.019, 2012.

Scheuvens, D., Schütz, L., Kandler, K., Ebert, M., and Weinbruch, S.: Bulk composition of northern African dust and its source sediments - A compilation, Earth-Sci. Rev., 116, 170 194, https://doi.org/10.1016/j.earscirev.2012.08.005, 2013.

Schmidt, S., Schneider, J., Klimach, T., Mertes, S., Schenk, L. P., Kupiszewski, P., Curtius, J., and Borrmann, S.: Online single particle analysis of ice particle residuals from mountain-top mixedphase clouds using laboratory derived particle type assignment, Atmos. Chem. Phys., 17, 575-594, https://doi.org/10.5194/acp17-575-2017, 2017.

Shen, X., Ramisetty, R., Mohr, C., Huang, W., Leisner, T., and Saathoff, H.: Laser ablation aerosol particle time-of-flight mass spectrometer (LAAPTOF): performance, reference spectra and classification of atmospheric samples, Atmos. Meas. Tech., 11, 2325-2343, https://doi.org/10.5194/amt-11-2325-2018, 2018.

Silva, P. and Prather, K.: Interpretation of mass spectra from organic compounds in aerosol time-of-flight mass spectrometry, Anal. Chem., 72, 3553-3562, 2000.

Sobanska, S., Hwang, H., Choël, M., Jung, H. J., Eom, H. J., Kim, H., Barbillat, J., and Ro, C. U.: Investigation of the chemical mixing state of individual asian dust particles by the combined use of electron probe X-ray microanalysis and raman microspectrometry, Anal. Chem., 84, 3145-3154, https://doi.org/10.1021/ac2029584, 2012.

Sodeman, D. A., Toner, S. M., and Prather, K. A.: Determination of single particle mass spectral signatures from lightduty vehicle emissions, Environ. Sci. Technol., 39, 4569-4580, https://doi.org/10.1021/es0489947, 2005.

Sullivan, R. C. and Prather, K. A.: Recent advances in our understanding of atmospheric chemistry and climate made possible by on-line aerosol analysis instrumentation, Anal. Chem., 77, 38613885, https://doi.org/10.1021/ac050716i, 2005.

Sullivan, R. C., Guazzotti, S. A., Sodeman, D. A., and Prather, K. A.: Direct observations of the atmospheric processing 
of Asian mineral dust, Atmos. Chem. Phys., 7, 1213-1236, https://doi.org/10.5194/acp-7-1213-2007, 2007a.

Sullivan, R. C., Guazzotti, S. A., Sodeman, D. A., Tang, Y., Carmichael, G. R., and Prather, K. A.: Mineral dust is a sink for chlorine in the marine boundary layer, Atmos. Environ., 41, 7166-7179, https://doi.org/10.1016/j.atmosenv.2007.05.047, $2007 \mathrm{~b}$.

Sullivan, R. C., Miñambres, L., Demott, P. J., Prenni, A. J., Carrico, C. M., Levin, E. J. T., and Kreidenweis, S. M.: Chemical processing does not always impair heterogeneous ice nucleation of mineral dust particles, Geophys. Res. Lett., 37, 1-5, https://doi.org/10.1029/2010GL045540, 2010a.

Sullivan, R. C., Petters, M. D., DeMott, P. J., Kreidenweis, S. M., Wex, H., Niedermeier, D., Hartmann, S., Clauss, T., Stratmann, F., Reitz, P., Schneider, J., and Sierau, B.: Irreversible loss of ice nucleation active sites in mineral dust particles caused by sulphuric acid condensation, Atmos. Chem. Phys., 10, 1147111487, https://doi.org/10.5194/acp-10-11471-2010, $2010 \mathrm{~b}$.

Tobo, Y., Zhang, D. Z., Nakata, N., Yamada, M., Ogata, H., Hara, K., and Iwasaka, Y.: Hygroscopic mineral dust particles as influenced by chlorine chemistry in the marine atmosphere, Geophys. Res. Lett., 36, L05817, https://doi.org/10.1029/2008GL036883, 2009.

Tsamalis, C., Chédin, A., Pelon, J., and Capelle, V.: The seasonal vertical distribution of the Saharan Air Layer and its modulation by the wind, Atmos. Chem. Phys., 13, 11235-11257, https://doi.org/10.5194/acp-13-11235-2013, 2013.

Usher, C. R., Michel, A. E., and Grassian, V. H.: Reactions on mineral dust, Chem. Rev., 103, 4883-4939, https://doi.org/10.1021/cr020657y, 2003.

Wonaschuetz, A., Kallinger, P., Szymanski, W., and Hitzenberger, R.: Chemical composition of radiolytically formed particles using single-particle mass spectrometry, J. Aerosol Sci., 113, 242249, https://doi.org/10.1016/j.jaerosci.2017.07.012, 2017.

Worringen, A., Kandler, K., Benker, N., Dirsch, T., Mertes, S., Schenk, L., Kästner, U., Frank, F., Nillius, B., Bundke, U., Rose, D., Curtius, J., Kupiszewski, P., Weingartner, E., Vochezer, P., Schneider, J., Schmidt, S., Weinbruch, S., and Ebert, M.: Single-particle characterization of ice-nucleating particles and ice particle residuals sampled by three different techniques, Atmos. Chem. Phys., 15, 4161-4178, https://doi.org/10.5194/acp15-4161-2015, 2015.
Yamaguchi, N., Ichijo, T., Sakotani, A., Baba, T., and Nasu, M.: Global dispersion of bacterial cells on Asian dust, Sci. Rep.-UK, 2, 525, https://doi.org/10.1038/srep00525, 2012.

Young, G., Jones, H. M., Darbyshire, E., Baustian, K. J., McQuaid, J. B., Bower, K. N., Connolly, P. J., Gallagher, M. W. and Choularton, T. W.: Size-segregated compositional analysis of aerosol particles collected in the European Arctic during the ACCACIA campaign, Atmos. Chem. Phys., 16, 4063-4079, https://doi.org/10.5194/acp-16-4063-2016, 2016.

Yuan, H., Rahn, K. A., and Zhuang, G.: Graphical techniques for interpreting the composition of individual aerosol particles, Atmos. Environ., 38, 6845-6854, https://doi.org/10.1016/j.atmosenv.2004.09.010, 2004.

Zawadowicz, M. A., Froyd, K. D., Murphy, D. M., and Cziczo, D. J.: Improved identification of primary biological aerosol particles using single-particle mass spectrometry, Atmos. Chem. Phys., 17, 7193-7212, https://doi.org/10.5194/acp17-7193-2017, 2017.

Zelenyuk, A., Yang, J., Choi, E., and Imre, D.: SPLAT II: An Aircraft Compatible, Ultra-Sensitive, High Precision Instrument for In-Situ Characterization of the Size and Composition of Fine and Ultrafine Particles, Aerosol Sci. Technol., 43, 411-424, https://doi.org/10.1080/02786820802709243, 2009.

Zelenyuk, A., Imre, D., Wilson, J., Zhang, Z., Wang, J., and Mueller, K.: Airborne Single Particle Mass Spectrometers (SPLAT II \& miniSPLAT) and New Software for Data Visualization and Analysis in a Geo-Spatial Context, J. Am. Soc. Mass Spectr., https://doi.org/10.1007/s13361-014-1043-4, 2015.

Zhu, A., Ramanathan, V., Li, F., and Kim, D.: Dust plumes over the Pacific, Indian, and Atlantic oceans: Climatology and radiative impact, J. Geophys. Res.-Atmos., 112, 1-20, https://doi.org/10.1029/2007JD008427, 2007.

Zimmermann, F., Weinbruch, S., Schütz, L., Hofmann, H., Ebert, M., Kandler, K., and Worringen, A.: Ice nucleation properties of the most abundant mineral dust phases, J. Geophys. Res.-Atmos. 113, D23204, https://doi.org/10.1029/2008JD010655, 2008. 